\title{
Emerging functional roles of nuclear receptors in breast cancer
}

\author{
Tram B Doan, J Dinny Graham and Christine L Clarke \\ Westmead Institute for Medical Research, Sydney Medical School - Westmead, University of Sydney,
} Sydney, New South Wales, Australia

Correspondence should be addressed to T B Doan

Email

tram.doan@sydney.edu.au

\begin{abstract}
Nuclear receptors (NRs) have been targets of intensive drug development for decades due to their roles as key regulators of multiple developmental, physiological and disease processes. In breast cancer, expression of the estrogen and progesterone receptor remains clinically important in predicting prognosis and determining therapeutic strategies. More recently, there is growing evidence supporting the involvement of multiple nuclear receptors other than the estrogen and progesterone receptors, in the regulation of various processes important to the initiation and progression of breast cancer. We review new insights into the mechanisms of action of NRs made possible by recent advances in genomic technologies and focus on the emerging functional roles of NRs in breast cancer biology, including their involvement in circadian regulation, metabolic reprogramming and breast cancer migration and metastasis.
\end{abstract}

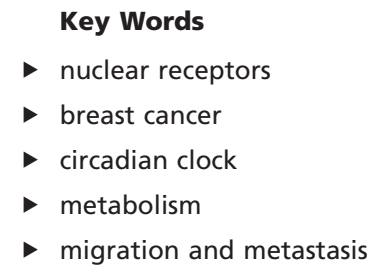

Journal of Molecular Endocrinology (2017) 58, R169-R190

\section{Introduction}

Breast cancer is the most common cancer diagnosed in women worldwide (Ferlay et al. 2015). Over the past decades, substantial progress toward treatment of primary estrogen receptor-positive (ER+) breast cancer has been made with the development of endocrine therapies targeting the estrogen biosynthesis and signaling pathways. Despite the success of endocrine therapies, there remain subgroups of women for whom available treatment offers little help. These include patients with ER+ breast tumors who develop endocrine treatment resistance (Dixon 2014), patients with estrogen receptornegative (ER-) breast cancers (Hudis \& Gianni 2011) and cancers that recur in all age groups (EBCTCG 2005). Women in these subgroups currently face the challenge of living with advanced disease; therefore, there exists the need to develop rational treatments targeting these subgroups of breast cancer.

Nuclear receptors (NRs) are potential promising targets due to the importance of NRs as master regulators of nearly all physiological aspects of life and the availability of drugs targeting NRs that resulted from intensive drug development targeting NRs for a range of pathological conditions. The human NR superfamily consists of 48 highly evolutionarily conserved transcription factors with the ability to act as molecular sensors of physiological and environmental stimuli (Mangelsdorf et al. 1995). Development of technologies that allow genome-wide, unbiased profiling of genomic binding sites and gene expression has allowed deeper insights into the molecular mechanisms of NR actions. These studies highlight the complexity of gene regulatory networks governed by NRs, the extensive nature of NR crosstalk and the role of coregulators and the chromatin landscape of the cell as important modulators of NR cell type-specific and context-dependent function.

In the context of breast cancer, it is recognized that estrogen receptor (ESR1) and progesterone receptor (PGR) play critical roles in the development and progression

Published by Bioscientifica Ltd 
of breast cancer, and moreover, their expression in a breast tumor remains the single most robust predictor of disease outcome. Consequently, measurement of ESR1 and PGR expression in breast cancers is a mainstay of clinical management programs and treatments targeting the estrogen signaling axis are standard of care for ER+ disease (Cordera \& Jordan 2006). More recently, the androgen receptor (AR), which is frequently expressed in primary breast tumors (Park et al. 2010, Grogg et al. 2015), has emerged both as a marker of outcome and as a potential treatment target (Cordera \& Jordan 2006, Barton et al. 2015). A number of other nuclear receptors, including the vitamin D3 receptor (VDR) (Krishnan et al. 2010, Mehta et al. 2013) and the glucocorticoid receptor (GR) (Vilasco et al. 2011, Abduljabbar et al. 2015b) have also been investigated for their anti-proliferative and anti-apoptotic effects in breast cancer. Members of the retinoid receptor subfamily have also received considerable attention, particularly the crosstalk between the retinoic acid receptor alpha (RARA) and estrogen signaling (Hua et al. 2009, Ross-Innes et al. 2010), and the anti-migratory effect of the retinoic acid receptor beta (RARB) in breast cancer (Yang et al. 2002, Flamini et al. 2014). However, the functional roles of the majority of the remaining members of the human NR family in the normal breast and breast cancer have largely been unexplored. Recent studies are establishing that the involvement of NRs in breast cancer extends beyond their involvement in regulating proliferation and apoptosis and that NRs are important regulators of several aspects of breast cancer tumorigenesis and progression including regulation of the circadian clock, metabolism, migration and metastasis. In this review, we will discuss evidence for these emerging functional roles of NRs in breast cancer, as well as new insights into the molecular mechanisms of action of NRs made possible through advances in genomic technologies.

\section{The nuclear receptor superfamily}

The human nuclear receptor superfamily consists of 48 members. These transcription factors include the receptors for steroid hormones, thyroid hormones, lipophilic vitamins and cholesterol metabolites including retinoic acid and oxysterols (Mangelsdorf et al. 1995). Members of the NR superfamily are identified through their highly evolutionarily conserved structural organization (Evans \& Mangelsdorf 2014), which consists of four major domains: The N-terminal A/B domain with activation function1 (AF1); the DNA-binding domain (DBD) consisting of two zinc finger motifs which confers response element specificity and the hinge region linking the DBD to the ligand-binding domain (LBD), which may or may not have an AF2 region that mediates coactivator interaction (Giguere et al. 1986, Kumar et al. 1987, Mangelsdorf et al. 1995) (Fig. 1A). Approximately half of the NRs are designated as orphans because endogenous physiological ligands for these NRs have not been found (Table 1). The 48 human NRs are organized into six evolutionary groups based on sequence alignment and phylogenetic tree construction (Auwerx et al. 1999, Germain et al. 2006). Organization of NRs into functional groupings is also feasible, based on profiling the anatomical expression of NRs. In the mouse, this revealed a hierarchical organization of NRs into integrated physiologic functional groups (Fig. 1B), which partially reflect the functional groupings observed in human, especially for NRs that are involved in circadian and metabolic pathways (reviewed here).

In the classical model of NR action, upon ligand activation, NRs regulate gene transcription by binding response elements within the regulatory regions of target genes as monomers, homodimers or heterodimers with another family member. For example, steroid hormone receptors generally bind as homodimers, whereas VDR, THR, RAR and RXR can form both homodimers and heterodimers. RXRs in particular can act as promiscuous heterodimerization partners for VDR, THR, RAR and orphan receptors. Dimerization is a general mechanism to increase binding affinity, specificity and diversity. Nuclear receptor response elements are derivatives of the canonical hexameric sequence RGGTCA. Modifications and duplications (organized as direct, inverted or everted repeats separated by a spacer with variable length) of this canonical hormone response element allow for selective recognition by different NR subclasses (Laudet \& Gronemeyer 2002, Gronemeyer et al. 2004).

Ligand binding also allosterically controls the interaction of NRs with coregulators by influencing the conformation of the AF2 region. Coregulators are integral to the mechanisms by which NRs exert their functions and include both coactivators and corepressors. The majority of coregulators function as members of large complexes that affect NR transcriptional regulation of target genes through interactions with other transcription factors, the chromatin landscape as well as non-coding RNAs (Millard et al. 2013). Both the interaction with coregulators and the chromatin landscape of the cell have been shown to affect the cell type specificity of NRs.

NRs regulate the transcription of genes that control a wide variety of biological processes in normal physiology

Published by Bioscientifica Ltd 

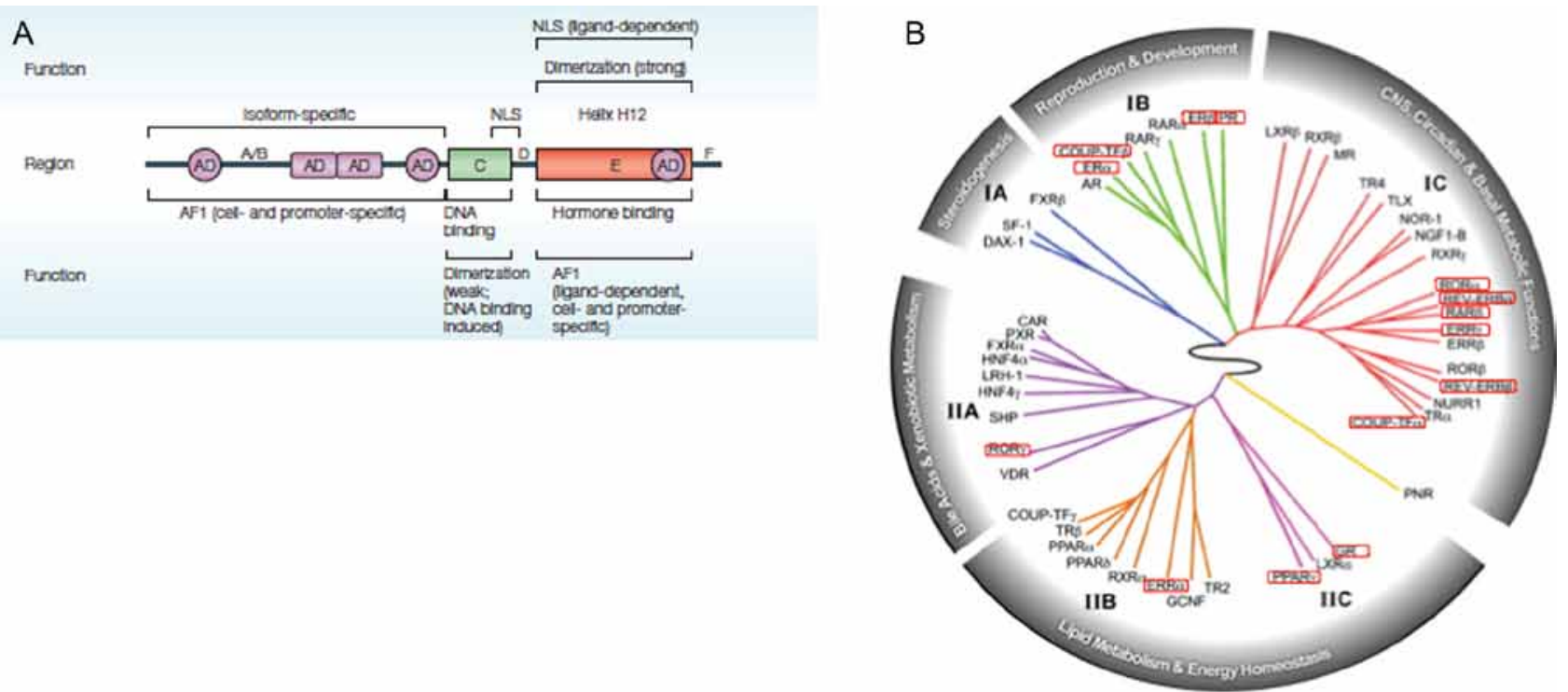

Figure 1

(A) Schematic diagram of the structural and functional organization of nuclear receptors (reprinted by permission from Macmillan Publishers Ltd: Nature Reviews Drug Discovery (Gronemeyer et al. 2004), copyright 2004). The evolutionary conserved regions $C$ and $E$ are indicated as boxes (green and orange, respectively), and a black bar represent the divergent regions $A / B, D$ and $F$. Domain functions are depicted above and below the scheme (AD, activation domain; AF1, activation function 1; NLS, nuclear localization signal). (B) Hierarchical clustering of NR tissue expression profile (reprinted from Cell, volume 126, Bookout AL, Jeong Y, Downes M, Yu RT, Evans RM \& Mangelsdorf DJ, Anatomical profiling of nuclear receptor expression reveals a hierarchical transcriptional network, pages 789-799, copyright (2006), with permission from Elsevier). The relationship between receptor expression, function and physiology is depicted as a circular dendrogram using the hierarchical, unsupervised clustering of NR tissue expression distribution profiles in mouse. The analysis reveals the existence of a higher order network tying nuclear receptor function to reproduction, development, central and basal metabolic functions, dietary-lipid metabolism and energy homeostasis. The NRs in red boxes are discussed in this review with a focus on their functional roles in circadian regulation, metabolism and breast cancer migration and metastasis.

including embryonic development, reproduction, metabolism, homeostasis and cell proliferation. NRs are also known to play a role in various pathological processes including cancer, inflammation and metabolic disorders (McKenna \& O'Malley 2010) and as such have been targets of intensive drug development for decades (Ottow \& Weinmann 2008).

\section{NR expression in the normal breast and breast cancer}

Recent studies have begun to provide a global view of the functional roles and expression of the NR superfamily in primary normal breast (Muscat et al. 2013) and breast cancer tissues (Muscat et al. 2013, Lin et al. 2015). Muscat and coworkers found that the majority of NRs are expressed in the breast (41 of 48). Many NRs showed differential expression in breast cancer compared to the normal breast indicative of potential involvement in breast cancer biology (Muscat et al. 2013). In particular, breast cancer is associated with the overexpression of the $N R 4 A$ subgroup as well as EAR2, and pan-repression of the majority of NRs relative to the normal breast. High expression of the NR4A subgroup in breast cancer was also observed by Lin and coworkers (Lin et al. 2015). In addition to ESR1, PGR and $A R$, expression levels of other NRs were shown to be associated with histological grade (THRB, NUR77, RORC, COUP-TF2 and LRH-1), to classify breast tissues (THRA, ESR1, NURR77, EAR2 and RARG) and to predict metastasis-free survival in tamoxifen-treated patients (THRB, COUP-TF2, MR and PPARG). Thirty-three of the 48 human NRs were also observed to be expressed in stromal cells and four of these (RORA, THRB, VDR and $P P A R G$ ) were shown to have differential expression profiles in cancer-associated fibroblasts compared to normal breast adipose fibroblasts (Knower et al. 2013). Together, these studies highlight that multiple members of the NR family are likely to play important roles in breast cancer growth and development and to have discriminant and prognostic value in breast cancer.

\section{NR expression in breast cancer subtypes}

Breast cancer is a heterogeneous disease encompassing multiple subtypes with distinct molecular profiles, therapeutic response and clinical outcomes (Prat et al. 2015). Several NRs have been shown to either act co-operatively with ESR1 and/or have differential

Published by Bioscientifica Ltd 
Table 1 Human nuclear receptors.

\begin{tabular}{|c|c|c|c|c|c|c|}
\hline Name & Nomenclature & Symbol & Entrez ID & Ligands & $\begin{array}{l}\text { Expression in BC } \\
\text { vs normal }\end{array}$ & $\begin{array}{l}\text { Association with } \\
\text { ESR1 expression }\end{array}$ \\
\hline \multicolumn{7}{|l|}{ Steroid hormone receptors } \\
\hline \multirow[t]{2}{*}{ Estrogen receptor } & NR3A1 & ESR1 & 2099 & Estogens & Increased & Yes $^{a, b}$ \\
\hline & NR3A2 & ESR2 & 2100 & Estradiols & Decreased & \\
\hline \multirow[t]{4}{*}{ 3-Ketosteroid receptor } & NR3C1 & GR & 2908 & $\begin{array}{l}\text { Cortisols } \\
\text { (hydrocortisone) }\end{array}$ & Increased & \\
\hline & $\mathrm{NR} 3 \mathrm{C} 2$ & MR & 4306 & Aldosterone & Decreased & \\
\hline & NR3C3 & PGR & 5241 & Progesterone & Expressed in $B C$ & Yesa,b \\
\hline & NR3C4 & AR & 367 & $\begin{array}{l}\text { Testosterone, } \\
\text { dihydrotestosterone }\end{array}$ & Increased & Yes $^{a, b}$ \\
\hline \multicolumn{7}{|c|}{ Non-steroid hormone receptors } \\
\hline \multirow[t]{2}{*}{ Thyroid hormone receptor } & NR1A1 & THRA & 7067 & $\begin{array}{l}\text { Thyroxine }\left(T_{4}\right) \\
\text { triiodothyronine }\left(T_{3}\right)\end{array}$ & Decreased & \\
\hline & NR1A2 & THRB & 7068 & $\begin{array}{l}\text { Thyroxine }\left(T_{4}\right) \\
\text { triiodothyronine }\left(T_{3}\right)\end{array}$ & Decreased & Yesa,b \\
\hline \multirow[t]{3}{*}{ Retinoic acid receptor } & NR1B1 & RARA & 5914 & $\begin{array}{l}\text { All-trans and 9-cis } \\
\text { retinoic acid }\end{array}$ & Increased & Yes $^{a, b}$ \\
\hline & NR1B2 & RARB & 5915 & $\begin{array}{l}\text { All-trans and 9-cis } \\
\text { retinoic acid }\end{array}$ & Decreased & \\
\hline & NR1B3 & RARG & 5916 & $\begin{array}{l}\text { All-trans and 9-cis } \\
\text { retinoic acid }\end{array}$ & Decreased & \\
\hline \multirow[t]{3}{*}{ RAR-related orphan receptor } & NR1F1 & RORA & 6095 & Oxysterols & Decreased & \\
\hline & NR1F2 & RORB & 6096 & $\begin{array}{l}\text { Cholesterol, cholesteryl } \\
\text { sulphate }\end{array}$ & Decreased & Yes $^{b}$ \\
\hline & NR1F3 & RORC & 6097 & Retinoic acid & Decreased & Yesb \\
\hline Vitamin D receptor & NR111 & VDR & 7421 & $\begin{array}{l}\text { Calcitriol }\left(1^{\prime}, 25^{\prime}\right. \\
\text { dihydroxy vitamin D3) }\end{array}$ & Decreased & \\
\hline \multicolumn{7}{|l|}{ Adopted orphans } \\
\hline \multirow{3}{*}{$\begin{array}{l}\text { Peroxisome proliferator- } \\
\text { activated receptor }\end{array}$} & NR1C1 & PPARA & 5465 & Fatty acids & Decreased & Yes $^{b}$ \\
\hline & NR1C2 & PPARD & 5467 & Fatty acids & Decreased & \\
\hline & NR1C3 & PPARG & 5468 & Fatty acids & Decreased & \\
\hline \multirow[t]{2}{*}{ Rev-erbs } & NR1D1 & REV-ERBa & 9572 & Heme & Decreased & \\
\hline & NR1D2 & REV-ERBb & 9975 & Heme & Decreased & \\
\hline \multirow[t]{3}{*}{ Liver $\mathrm{X}$ receptor-like } & $\mathrm{NR} 1 \mathrm{H} 2$ & $\mathrm{LXRb}$ & 7376 & Retinoic acid & Decreased & \\
\hline & $\mathrm{NR} 1 \mathrm{H} 3$ & LXRa & 10062 & Oxysterols & Decreased & \\
\hline & NR1H4 & FXRa & 9971 & Bile acids & Not expressed & \\
\hline \multirow[t]{2}{*}{ Vitamin D receptor-like } & NR1I2 & PXR & 8856 & Bile acids & Decreased & \\
\hline & NR113 & CAR & 9970 & $\begin{array}{l}\text { Androstanol, } \\
\text { androstenol }\end{array}$ & Not expressed & \\
\hline \multirow[t]{3}{*}{ Retinoid $\mathrm{X}$ receptor } & NR2B1 & RXRA & 6256 & 9-cis-retinoic acid & Decreased & \\
\hline & NR2B2 & $\mathrm{RXRB}$ & 6257 & 9-cis-retinoic acid & Decreased & \\
\hline & NR2B3 & RXRG & 6258 & 9-cis-retinoic acid & Decreased & \\
\hline \multirow[t]{2}{*}{ Steroidogenic factor-like } & NR5A1 & SF-1 & 2516 & Phospholipids & Not expressed & \\
\hline & NR5A2 & LRH-1 & 2494 & Phospholipids & Decreased & Yes \\
\hline \multicolumn{7}{|l|}{ Orphan nuclear receptors } \\
\hline $\begin{array}{l}\text { DSS-AHC critical region on the } \\
\text { X chromosome, gene } 1\end{array}$ & NROB1 & DAX-1 & & Not known & Not expressed & Yes \\
\hline Short heterodimeric partner & NROB2 & SHP & 8431 & CD437 retinoids & Not expressed & \\
\hline \multirow[t]{2}{*}{ Hepatocyte nuclear factor 4} & NR2A1 & HNF4a & 3172 & Fatty acids & Not expressed & \\
\hline & NR2A2 & HNF4g & 3174 & Fatty acids & Decreased & \\
\hline \multirow[t]{2}{*}{ Testicular orphan receptors } & $\mathrm{NR} 2 \mathrm{C} 1$ & TR2 & 7181 & All-trans retinoic acid & Decreased & \\
\hline & $\mathrm{NR} 2 \mathrm{C} 2$ & TR4 & 7182 & All-trans retinoic acid & Decreased & \\
\hline Tailess-related receptor & NR2E1 & TLX & 7101 & Not known & Not expressed & Yes $^{b}$ \\
\hline $\begin{array}{l}\text { Photoreceptor cell-specific } \\
\text { receptor }\end{array}$ & NR2E3 & PNR & 10002 & Benzimidazoles & Decreased & $Y_{e s}^{a, b}$ \\
\hline \multirow{2}{*}{$\begin{array}{l}\text { Chicken ovalbumin upstream } \\
\text { promoter-transcription factor }\end{array}$} & $\mathrm{NR} 2 \mathrm{~F} 1$ & COUP-TF1 & 7025 & Not known & Decreased & \\
\hline & NR2F2 & COUP-TF2 & 7026 & Retinol/ATRA & Decreased & \\
\hline
\end{tabular}


Table 1 Continued.

\begin{tabular}{|c|c|c|c|c|c|c|}
\hline Name & Nomenclature & Symbol & Entrez ID & Ligands & $\begin{array}{l}\text { Expression in } B C \\
\text { vs normal }\end{array}$ & $\begin{array}{l}\text { Association with } \\
\text { ESR1 expression }\end{array}$ \\
\hline ErbA2-related gene 2 & NR2F6 & EAR2 & 2063 & Not known & Increased & \\
\hline \multirow[t]{3}{*}{$\begin{array}{l}\text { Estrogen receptor-related } \\
\text { receptor }\end{array}$} & NR3B1 & ESRRA & 2101 & $\begin{array}{l}\text { Isoflavones, } \\
\text { diethylstilbestrol, } \\
\text { chlordane }\end{array}$ & Decreased & \\
\hline & NR3B2 & ESRRB & 2103 & $\begin{array}{l}\text { Isoflavones, } \\
\text { diethylstilbestrol, } \\
\text { 4-hydroxy tamoxifen }\end{array}$ & Decreased & \\
\hline & NR3B3 & ESRRG & 2104 & $\begin{array}{l}\text { Isoflavones, } \\
\text { diethylstilbestrol, } \\
\text { 4-hydroxy tamoxifen }\end{array}$ & Decreased & Yesb \\
\hline \multirow[t]{3}{*}{ Nerve growth factor IB-like } & NR4A1 & NUR77 & 3164 & $\begin{array}{l}\text { Cyclosporone-B, } \\
\text { diindolylmethane } \\
\text { analogs }\end{array}$ & Increased & \\
\hline & NR4A2 & NURR1 & 4929 & $\begin{array}{l}\text { 6-Mercaptopurine, } \\
\text { benzimidazoles, } \\
\text { C-DMls }\end{array}$ & Increased & \\
\hline & NR4A3 & NOR1 & 8013 & $\begin{array}{l}\text { 6-Mercaptopurine, } \\
\text { prostaglandin A2 }\end{array}$ & Increased & \\
\hline Germ cell nuclear factor & NR6A1 & GCNF & 2649 & Not known & Decreased & \\
\hline
\end{tabular}

aMuscat et al. (2013); bLin et al. (2015).

actions in ER+ vs ER- breast cancers. For instance, AR has different roles in ER+ vs ER- breast cancers. AR has been investigated extensively as a therapeutic target in ER- breast cancer. It was reported that in ER-/HER2+ breast tumors, AR stimulates oncogenic Wnt and HER2 signaling pathways thereby stimulating cancer cell growth (Ni et al. 2011). However, the role of androgen signaling in ER+ breast cancer is less clear. Expression of AR is associated with good prognosis in ER+ breast cancer (Hu et al. 2011, Hilborn et al. 2016), with anti-estrogenic and anti-proliferative effects in ER+ breast cancer being reported (Peters et al. 2009, D'Amato et al. 2015). The anti-proliferative effect of $\mathrm{AR}$ is partly attributed to its inhibitory effect on ESR1 signaling in ER+ breast cancer cells (Peters et al. 2009, Fioretti et al. 2014). However, AR has also been reported to contribute to therapy resistance in ER+ breast cancer cells overexpressing AR, with increase in AR-to-ESR1 ratio associated with worse outcome for tamoxifen-treated patients (Cochrane et al. 2014) and increased agonist activity of Tam in AR overexpressing cells. In this context, AR reportedly increased tamoxifen agonist activity via the activation of EGFR in ER+ breast cancer, and this was blocked by dual treatment with the anti-androgen enzalutamide and EGFR inhibitor gefitinib (Ciupek et al. 2015). In addition, AR appears to promote proliferation of molecular apocrine breast cancer; a subset of TNBC expressing AR, through activation of genes that are normally regulated by ESR1 in ER+ cancer (Robinson et al. 2011).
Similarly, the expression of GR has been shown to be differentially associated with survival in ER+ vs ER- breast cancers. In ER+ breast cancers, high GR expression is associated with better survival (Pan et al. 2011, Abduljabbar et al. 2015b), whereas in ER- breast cancers, high GR expression is correlated with poorer breast cancer-specific survival (Pan et al. 2011, Abduljabbar et al. 2015b).

Recent studies profiling the expression of NRs in ER+ and ER- cancers have also identified other NRs whose expression levels differ significantly between ER+ and ER- breast cancers (Table 1). In particular, $A R, P G R$, $P N R, R A R A$ and THRB were reported to be significantly differentially expressed between ER+ and ER- breast cancers (Muscat et al. 2013) and significantly associated with ESR1 expression (Lin et al. 2015). The expression of DAX-1, LRH-1, PPARA, RORB, RORC and TLX were also reported to be significantly associated with ESR1 expression in multiple microarray datasets (Lin et al. 2015).

\section{Mechanisms of NR action}

Alterations in normal transcriptional programs are a fundamental feature of cancer pathogenesis and progression. Nuclear receptors are important regulators that directly couple small-molecule signaling with transcriptional regulation. An understanding of their mechanisms of action at the genomic and network level, and how these processes are altered in breast cancer, is of

Published by Bioscientifica Ltd. 
fundamental importance to our understanding of breast cancer development.

The development of technologies such as ChIPchip, ChIP-Seq and GRO-Seq has enabled profiling of the genomic locations of NR binding in an unbiased, genomewide manner. Studies employing these methods have revealed new insights into the mechanisms of action of nuclear receptors and highlight the complexity of nuclear receptor regulatory networks in breast cancer. In this subsection, we review new insights of NR mechanisms of action in breast cancer made possible by these genomic methods.

\section{Shifts from the 'classical' model of NR action}

Traditionally, studies on nuclear receptor action at hormone-responsive genes gave rise to the model that NRs bind proximally to the promoters of target genes, through recognition of stringent paired half-sites with highly specific orientation (Mangelsdorf et al. 1995). However, these classical models have been challenged by recent studies that profiled the genome-wide binding sites of several nuclear receptors and transcription factors using ChIP-chip or ChIP-Seq. In the context of breast cancer, genome-wide mapping of ESR1 genomic localization in the MCF-7 breast cancer cell line showed that most ESR1 binding occurs at distal regions of the genome and that many ESR1 sites did not contain the canonical ESR1-binding motif (Carroll et al. 2006). Kittler and coworkers examined the genomic distribution of the binding sites of 24 NRs in MCF-7 cells and found that NR varied significantly in their genomic localization, with both proximal-biased and distal-biased NRs being observed (Kittler et al. 2013). The observation that NRs localize not only to proximal promoter regions but also to distal regions and the prevalence of noncanonical motif and half-site recognition is also confirmed in a meta-analysis of NR cistromes in different cell types (Tang et al. 2011). NR binding at non-canonical response elements can be a mechanism to fine tune transcriptional responses of NR. For example, the glucocorticoid receptor (GR) is capable of binding a negative response element (nGRE) that confers transrepression in addition to the canonical glucocorticoid response elements (GRE) that confers transactivation to liganded GR in epidermis and intestinal epithelial cells (Surjit et al. 2011). Furthermore, NRs are capable of mediating long-range transcriptional regulation that involves chromatin looping as illustrated by studies on the estrogen receptor-mediated long-range chromatin interactions (Liu \& Cheung 2014). Together, these studies suggest a more complex model of NR genomic action in which NRs frequently act on long-range enhancers whose actions can be fine-tuned by recognition of different response elements.

\section{Cell type specificity and the chromatin landscape}

Studies investigating NR cistromes highlight the remarkable difference in the genome-wide binding profiles of the same NR in different cell types (Krum et al. 2008, Clarke \& Graham 2012). In addition to the influence of coregulators in determining the cell type-specific transcriptional response of NRs (discussed in the next section), another major aspect of NR action illuminated through advances in genomic technologies is the dynamic and complex interactions between NR and the chromatin landscape of the cell. It is becoming clear that chromatin, existing in a dynamic continuum of condensation states, regulates as well as is regulated by, NR actions, and that NR-chromatin interaction is a major determinant of NR cell type-specific transcriptional regulation. Due to the widely accepted model of NR binding to DNA only after conformational changes induced upon ligand binding, several groups have investigated the question of preinduction vs post-induction chromatin as a determinant of NR action. Genome-wide screening of DNAse I hypersensitive sites (DHS) in breast cells revealed that the majority (>70\%) of GR binding occurs at pre-induction DHS sites, whereas only $20 \%$ of GR binding occurs at hormone-induced remodeled chromatin (John et al. 2011). A recent study of long-range interactions before and after dexamethasone induction in HeLa cells found that, similar to breast cells, the majority of GR binding occurs at pre-accessible chromatin. Binding of GR to a subset of sites containing the consensus GRE results in the formation of active enhancers and increased longrange interactions (Kuznetsova et al. 2015). Profiling of ESR1 revealed a similar pattern. The majority of ESR1binding sites coincide with pre-existing open chromatin, co-occurrence of other transcription factor binding, and correspond to cell type-specific gene regulation, whereas ESR1-binding sites shared by multiple cell types are characterized by inaccessible chromatin containing highaffinity estrogen response elements (Gertz et al. 2013). Profiling of the PGR by DNase and Micrococcal nuclease (MNase) followed by next-generation sequencing showed that PGR binding upon hormone stimulation corresponds with DHS regions that still exhibit high nucleosome occupancy. Upon hormone treatment, remodeling of nucleosomes containing functional PGR-binding sites occurs, and progesterone-responsive genes are associated with PGR-binding sites that show strong nucleosome

Published by Bioscientifica Ltd. 
remodeling upon hormone induction (Ballare et al. 2013). The chromatin landscape of the cell therefore plays an important role in determining the genomic binding profiles of specific NRs. Although some NRs such as ESR1and GR rely mostly on pre-programmed sites made accessible by other cell- and tissue-specific pioneer DNAbinding factors, other NRs such as PGR require liganddependent active chromatin remodeling.

\section{Pioneer factors and coregulators as modulators of NR function}

Pioneer factors are transcription factors that can bind condensed chromatin and influence transcription by facilitating subsequent recruitment of other transcriptional regulators. Recent studies have highlighted the importance of pioneer factors in facilitating chromatin accessibility and also in determining the cell type-specific response of NRs. This is exemplified by the dependence of ESR1 on FOXA1 in breast cancer. FOXA1 expression is luminal restricted (Perou et al. 2000) and is thought to function as a pioneer factor (Cirillo et al. 2002). FOXA1 has been observed to influence genome-wide chromatin accessibility and is a key determinant of cell type-specific ESR1 genomic localization (Lupien et al. 2008, Hurtado et al. 2011), reflecting the importance of interaction with other factors on control of cell specificity of ESR1. Similarly, AP-1 has been shown to recruit GR to regions of the genome that are basally accessible prior to hormonal treatment. AP-1 is thought to maintain chromatin accessibility for GR binding as well as recruiting GR indirectly in the absence of a canonical GR motif (Biddie et al. 2011).

In addition to pioneer factors, coregulators interact with NRs and other transcription factors to facilitate transcription of target genes. According to the Nuclear Receptor Signaling Atlas (NURSA: www.nursa.org), there are $320 \mathrm{NR}$ coregulators identified to date. However, this number is likely to be a gross underestimation according to a recent proteomic study (Malovannaya et al. 2011). Coregulators can assist in transcriptional regulation of NRs by facilitating chromatin accessibility, stabilizing NR-DNA interaction or facilitating indirect NR-DNA interaction through tethering (McKenna \& O'Malley 2002, Millard et al. 2013).

Selective recruitment of coregulators to subsets of NR-binding sites can also be a mechanism through which transcriptional regulation of subsets of NR target genes are fine-tuned. An early study of ESR1 and steroid receptor coactivator protein (SRC) binding using promoter tiling arrays showed E2-dependent recruitment of ESR1 and
SRC to E2-stimulated genes while the absence of SRC was observed at E2-repressed genes (Kininis et al. 2007). In a subsequent study, Zwart and coworkers mapped the genome-wide binding sites of several ESR1 coregulators (SRC1, SRC2, SRC3, p300 and CBP) in MCF-7 cells and showed a complex network of ESR1-coregulator binding, with preferential binding sites for each coregulator. They identified a subset of ESR1-regulated genes that are co-occupied by SRC3, but not SRC1 or SRC2, that predicts poor or good survival outcome depending on whether the genes were upregulated or downregulated (Zwart et al. 2011). Lupien and coworkers also identified association between a subset of E2-induced ESR1 binding sites co-occupied by CARM1 and gene repression, independent of the presence of FOXA1 binding. They also identified another subset of E2-induced, FOXA1-independent, ESR1 and CARM1 co-occupied sites that result primarily in repression of expression (Lupien et al. 2009). These studies demonstrate that selective interaction with different coregulators at specific subsets of target genes may be an important mechanism through which the specificity of NR action is modulated.

Due to their central role in regulating NR-mediated transcription, many coregulators are known to be involved in human diseases (Lonard et al. 2007, Lonard \& O'Malley 2012). In the breast, changes in expression levels of coregulators have been implicated in the tissuespecific response to tamoxifen (Keeton \& Brown 2003). The majority of coregulators show differential expression between breast cancer and normal breast tissues, as well as between ER+ and ER- breast cancers. This is accompanied by changes in the expression correlations between subsets of coregulators and specific NRs, whose expression showed prognostic value in breast cancer (Doan et al. 2014).

Coregulators are therefore critical determinants of NR-mediated transcriptional regulation in the breast and disruptions in the normal NR-coregulator interaction network are potentially an important aspect of breast cancer biology.

\section{Combinatorial control of gene expression by NRs in breast cancer}

Recent large-scale integrative analyses of transcription factor genomic localization data from the ENCODE project highlighted the extraordinary complexity of transcriptional regulation and the extensive functional crosstalk between transcription factors (ENCODE Project Consortium 2012, Gerstein et al. 2012, Xie et al. 2013). This observation also holds for NR in breast cancer.

Published by Bioscientifica Ltd 
Kittler and coworkers (Kittler et al. 2013) built a regulatory map from cistromic data of 24 NRs and 14 breast cancerassociated coregulators in MCF-7 breast cancer cells. They showed that the resulting network is highly interconnected and there are many regions in the genome coordinately occupied by multiple NRs (HOT regions). These HOT regions are enriched with features associated with active regulatory elements, including active chromatin marks and increased chromatin accessibility. These regions are also enriched with breast cancerrelevant genes and are hypothesized to be important active regulatory regions in breast cancer cells.

On a smaller scale, other studies have also revealed convergence in genomic binding between ESR1 and various other NRs in breast cancer cells by individually comparing the overlap of their cistromes. ESR1 is known to drive growth and proliferation in the majority of breast tumors. Mounting evidence indicates that ESR1 does not act on its own and that other transcription factors, including other NRs, are important determinants of ESR1 action in breast cancer cells. For example, retinoic acid has been known to inhibit proliferation in breast cancer cells and antagonize the growth stimulation effect of estrogen (Fontana et al. 1992). Studies of ESR1 and RARA cistromes showed that ESR1 and RARA share very similar binding profiles, although whether the interaction is antagonistic or co-operative is still controversial (Hua et al. 2009, RossInnes et al. 2010). Likewise, cistromic profiling of ESR1 and GR in mouse mammary epithelial cell lines revealed significant co-operation of these two NRs, through an assisted loading mechanism, in which binding of one NR facilitates chromatin remodeling thereby enabling access to DNA for the other NR (Miranda et al. 2013). Another study profiling ESR1 and GR genomic localization in MCF-7 cells revealed that, although GR co-occupies several ESR1-binding sites in cells treated with both E2 and dexamethasone, GR recruitment to these sites is associated with displacement of ESR1 leading to the repression of estrogen receptor-mediated transcriptional activation of target genes (Karmakar et al. 2013). Therefore, although ESR1 co-occupies many target genes with RARA as well as $\mathrm{GR}$, the nature of their interaction is reported to be both co-operative and antagonistic, perhaps reflecting different time, target and cell-specific modes of co-operation between these NRs.

In addition to RARA and GR, ESR1 was reported to share genomic binding sites with PGR and LRH-1. In the presence of both estrogen and progesterone, PGR was shown to be recruited to the ESR1 complex and to redirect ESR1-binding events, resulting in a gene expression profile associated with better clinical outcome (Mohammed et al. 2015). However, in the presence of estrogen alone, un-liganded PGRB activated a subset of ER target genes by acting as a molecular scaffold for the formation of a transcriptional complex with ESR1 and PELP1, resulting in a more aggressive proliferative response to estrogen (Daniel et al. 2015). It is likely that the action of ESR1 and PGR and their crosstalk are highly context dependent. Furthermore, the majority of data are derived from cell line models, and the implications for breast cancer in vivo are yet to be established. LRH-1 was reported to share a substantial portion $(\sim 35 \%)$ of its binding sites with that of ESR1 and synergistically regulate a subset of estrogenresponsive genes in MCF-7 cells (Lai et al. 2013).

These studies highlight the complexity of cross talk, particularly between ER and other NRs, in gene regulatory networks and the utility of integrated, genome-wide analyses in unraveling this complexity. Whether the studies so far reflect transcriptional plasticity that is particularly a feature of ER or whether data will emerge supporting this as a mechanism common to other NRs is still to be determined; nevertheless, these insights into the functional interactions between NRs in breast cancer have the potential to lead to novel therapeutic strategies.

\section{Reprogramming of NR binding and disease progression}

It is becoming increasingly evident that transcriptional regulation is a highly dynamic process with transcription factors displaying temporal, cell type specific and disease-associated shifts in their genomic binding profiles. The transcriptional targets of PGR in T-47D breast cancer cells and AB-32 immortalized normal breast cells display remarkably low overlap (Clarke \& Graham 2012), reflecting cancer-associated and cell type-specific changes in PGR transcriptional regulation. Recent studies have highlighted the effect of changes in NR transcriptional programs and their association with breast cancer disease progression and clinical outcomes. Ross-Innes and coworkers performed ChIPseq of ESR1 in clinical samples with different prognoses to directly explore the correlation between ESR1 binding and cancer progression (Ross-Innes et al. 2012). They observed high signal intensity at ESR1-binding sites in metastatic samples, whereas lower ESR1 signal intensity was observed in samples with good prognosis. Further, they showed that ESR1 binding is a highly dynamic process, with distinct ESR1-binding regions observed in samples with different outcomes. This dynamic change in ESR1 action was shown to be influenced by

Published by Bioscientifica Ltd. 
the action of other NRs, such as PGR (Mohammed et al. 2015), as well as the signaling context leading to ESR1 activation. For example, ESR1 displayed distinct genomic binding profiles depending on whether ESR1 was activated by estrogen or through the epidermal growth factor (EGF) pathway (Lupien et al. 2010). The EGF-induced ESR1 cistrome specifically regulates genes that are overexpressed in ERBB2-positive breast cancers and associated with poor clinical outcomes. The EGF pathway can therefore be an alternative activator for ESR1 signaling in breast cancer and provides a molecular explanation for the endocrine therapy resistance often seen in ER+ERBB2+ breast cancers. Analysis of ESR1 and ESRRA cistromes in tamoxifen-sensitive vs -resistant breast cancer cells showed that despite regulating distinct transcriptional networks, their cistromes are reprogramed in tamoxifen-resistant breast cancer cells toward the regulation of genes functionally relevant to resistance (Thewes et al. 2015). These studies show that NR binding profiles can be shifted in a contextdependent manner, resulting in altered transcriptional networks that affect disease progression and outcome.

\section{Emerging functional roles of NR in BC}

It is now clear that a number of NRs are implicated in breast cancer growth and development (Conzen 2008). It is emerging that, in addition to influencing cell growth and proliferation, NRs also play important roles in other aspects of breast cancer biology. Table 2 summarizes reported involvement of NRs in selected aspects of breast cancer biology. This section outlines some of the emerging functional roles of NRs in breast cancer.

\section{Nuclear receptors as key components of the circadian clock}

A circadian rhythm is any biological process that displays an endogenous, entrainable oscillation cycle of roughly $24 \mathrm{~h}$, driven by a self-sustained timekeeping mechanism, the circadian clock. The circadian clock governs many aspects of human physiology, including body temperature, sleep-wake cycle, blood pressure, hormone secretion and metabolism. In line with this, at least $10 \%$ of all genes are under the control of the circadian system and display

Table 2 NR function in breast cancer. ${ }^{a}$

\begin{tabular}{|c|c|c|c|c|c|c|c|c|c|c|}
\hline Nomenclature & Symbol & $\begin{array}{l}\text { Anti-proli- } \\
\text { ferative }\end{array}$ & $\begin{array}{c}\text { Pro- } \\
\text { apoptotic }\end{array}$ & $\begin{array}{c}\text { Anti- } \\
\text { migratory }\end{array}$ & $\begin{array}{c}\text { Pro-oxidative } \\
\text { phosphoryla- } \\
\text { tion }\end{array}$ & $\begin{array}{c}\text { Pro- } \\
\text { proliferative }\end{array}$ & $\begin{array}{c}\text { Anti- } \\
\text { apoptotic }\end{array}$ & $\begin{array}{c}\text { Pro- } \\
\text { migratory }\end{array}$ & $\begin{array}{c}\text { Pro- } \\
\text { glycolytic }\end{array}$ & $\begin{array}{c}\text { Circadian } \\
\text { involve- } \\
\text { ment }\end{array}$ \\
\hline NR3A1 & ESR1 & & & & & $\mathrm{Y}$ & & $Y$ & & $Y$ \\
\hline NR3A2 & ESR2 & $\mathrm{Y}$ & & $\mathrm{Y}$ & & & & $\mathrm{Y}$ & & \\
\hline NR3C1 & GR & & & & & & $\mathrm{Y}$ & & & $\mathrm{Y}$ \\
\hline NR3C3 & PGR & & & $Y$ & & $\mathrm{Y}$ & $Y$ & $Y$ & & \\
\hline NR3C4 & AR & $Y$ & & & & $Y$ & & & & \\
\hline NR1B1 & RARA & $Y$ & $\mathrm{Y}$ & & & & & & & \\
\hline NR1B2 & RARB & $\mathrm{Y}$ & $\mathrm{Y}$ & $\mathrm{Y}$ & & & & & & \\
\hline NR1B3 & RARG & $\mathrm{Y}$ & $\mathrm{Y}$ & & & & & & & \\
\hline NR1F1 & RORA & & & & & & & & & $\mathrm{Y}$ \\
\hline NR1F2 & RORB & & & & & & & & & $Y$ \\
\hline NR1F3 & RORC & & & & & & & & & $\mathrm{Y}$ \\
\hline NR1I1 & VDR & $\mathrm{Y}$ & $\mathrm{Y}$ & & & & & & & \\
\hline NR1C1 & PPARA & & & & & $\mathrm{Y}$ & & & & \\
\hline NR1C2 & PPARD & & & & & $\mathrm{Y}$ & & & & \\
\hline NR1C3 & PPARG & $\mathrm{Y}$ & $\mathrm{Y}$ & & & $\mathrm{Y}$ & $\mathrm{Y}$ & & & \\
\hline NR1D1 & REV-ERBa & $\mathrm{Y}$ & & & $\mathrm{Y}$ & & & & & $\mathrm{Y}$ \\
\hline NR1D2 & REV-ERBb & $\mathrm{Y}$ & & & & & & & $Y$ & $\mathrm{Y}$ \\
\hline NR2B1 & $\mathrm{R} \times \mathrm{RA}$ & & $Y$ & & & & & & & \\
\hline NR2B2 & $\mathrm{RXRB}$ & & $Y$ & & & & & & & \\
\hline NR2B3 & $\mathrm{RXRG}$ & & $\mathrm{Y}$ & & & & & & & \\
\hline NR2F1 & COUP-TF1 & & & & & & & $\mathrm{Y}$ & & \\
\hline NR2F2 & COUP-TF2 & & & & & & & $\mathrm{Y}$ & & \\
\hline NR3B1 & ESRRA & & & & & & & $Y$ & $\mathrm{Y}$ & \\
\hline NR3B3 & ESRRG & & & $\mathrm{Y}$ & $\mathrm{Y}$ & & & & & \\
\hline NR4A1 & NUR77 & & & & & & & $Y$ & & \\
\hline
\end{tabular}

aNR effect on cancer-related biological processes based on studies in breast primary tissue or cell lines. The influence of NR on breast cancer proliferation, apoptosis, migration, metabolism as well as involvement in circadian regulation/response is tabulated.

$\mathrm{Y}$, indicates reported involvement.

http://jme.endocrinology-journals.org DOI: $10.1530 / \mathrm{JME}-16-0082$
(C) 2017 Society for Endocrinology Printed in Great Britain
Published by Bioscientifica Ltd 
circadian oscillation (Akhtar et al. 2002, Oishi et al. 2003, 2005). There is mounting evidence linking circadian disruption to various clinical and pathological conditions including cancer. Here, we discuss the emerging link between NRs and circadian regulation, as well as the growing body of evidence linking circadian disruption and breast cancer.

Initially, the circadian clock was defined to be a relatively simple feedback loop consisting of the key transcription factors CLOCK and BMAL and their co-repressors, PER and CRY (Fig. 2). It is now emerging that the circadian clock contains other auxiliary loops that involve multiple NRs, most prominently REV-ERBs and RORs (Fig. 2, reused from Bechtold et al. (2010), with permission from Elsevier). RORs recognize the same regulatory elements as REV-ERBs, and a range of studies have demonstrated their importance in the regulation of clock gene expression (Akashi \& Takumi 2005). Gene deletion studies and cistrome analyses have confirmed the pivotal role of REV-ERBs in the universal circadian machinery (Preitner et al. 2002).

In addition to REV-ERBs and RORs, several other NRs have been shown to regulate as well as being regulated by the circadian clock, most notably GR (ConwayCampbell et al. 2010) and ESRRA (Dufour et al. 2011). The list of other NRs potentially under control of the circadian clock is extensive, with at least 35 NRs known to display circadian expression in various metabolic tissues (Zhao et al. 2014).

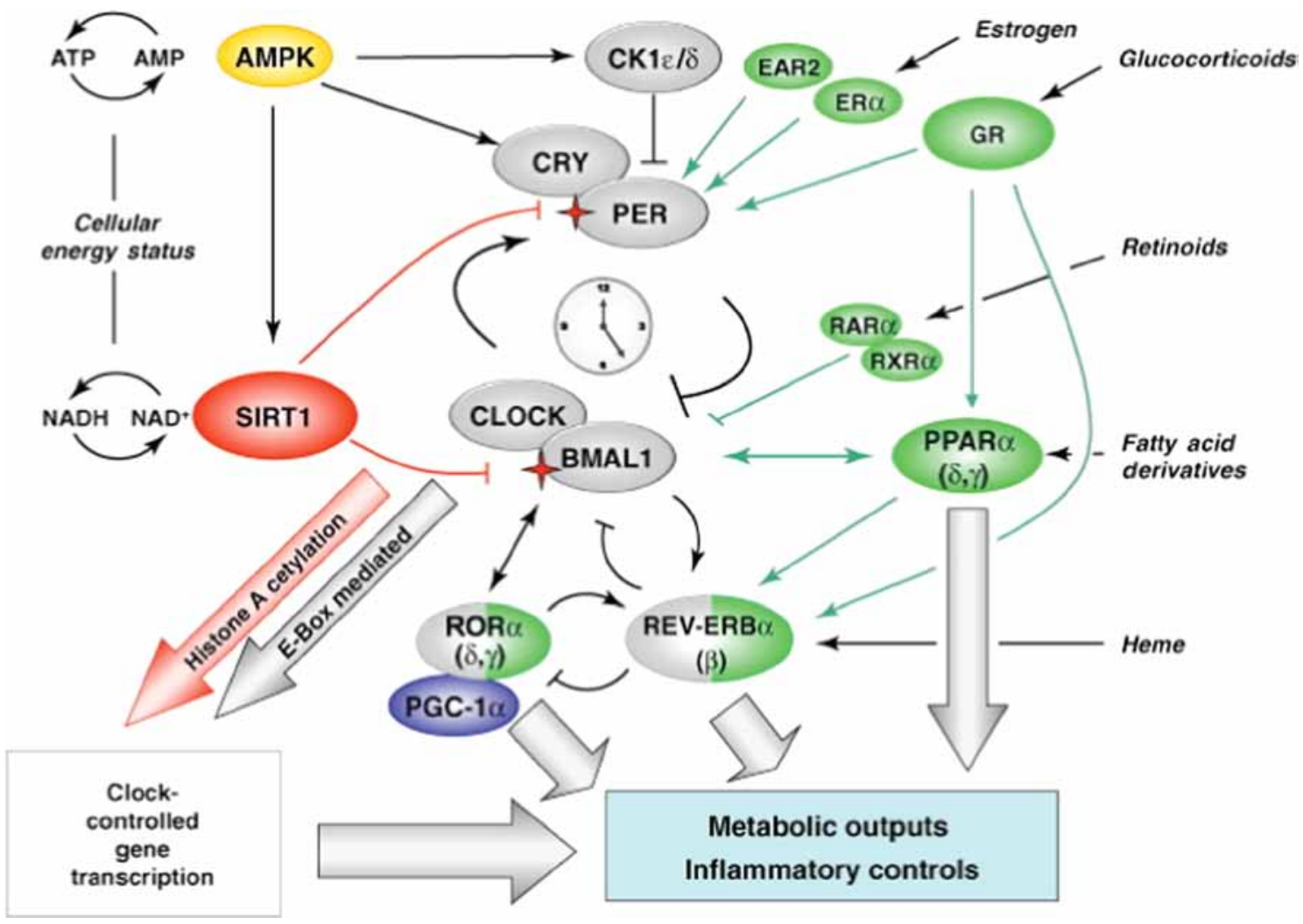

Figure 2

The molecular clock machinery (reprinted from Trends in Pharmacological Sciences, volume 31, Bechtold DA, Gibbs JE \& Loudon AS, Circadian dysfunction in disease, pages 191-198, copyright (2010), with permission from Elsevier). The molecular machinery that provides circadian timekeeping consists of a complex circuitry of transcriptional/translational regulatory feedback loops (clock components shown in gray). In mammals, the current model involves a primary loop with CLOCK (or homologue NPAS2) and BMAL1 as transcriptional activators, and PERIOD (PER1, PER2 and PER3) and CRYPTOCHROME proteins (CRY1 and CRY2) as transcriptional repressors. As levels of cytosolic PER and CRY proteins rise, they associate, translocate to the nucleus and repress their own gene transcription through direct interaction with the CLOCK/BMAL1 complex. This feedback cycle provides near 24-h timing and drives the rhythmic expression of several clock-controlled and clock-modulated genes, which in turn mediate circadian rhythms in behavior and physiology. Acting on the primary feedback loop are auxiliary loops, which appear to increase the stability and robustness of the oscillations. The most notable interlocking loop is that involving the nuclear hormone receptors (NRs), REV-ERB and ROR. In addition to REV-ERB and ROR, several other NRs (shown in green) interact closely with the circadian feedback loops and are responsive to the clock (exhibit rhythmic expression) and able to feedback onto the clock genes themselves. NR regulation of clock genes also renders the clock responsive to numerous circulating hormones (e.g. cortosol, estrogen), nutrient signals (e.g. derivatives of fatty acids and retinoids) and cellular redox status (NADH/NAD+ ratio).

http://jme.endocrinology-journals.org DOI: 10.1530/JME-16-0082
๑) 2017 Society for Endocrinology Printed in Great Britain
Published by Bioscientifica Ltd 
To date, epidemiological studies reported mixed findings on the association between increased risk of breast cancer and circadian disruption in the form of night shift work. Although a few studies reported no significant association between breast cancer and night work (O'Leary et al. 2006, Pronk et al. 2010), the majority of recent studies reported significant or borderline associations, with the strongest association found with long-term exposure to night work (Hansen 2001, Schernhammer et al. 2001, 2006, Hansen \& Lassen 2012, Hansen \& Stevens 2012, Knutsson et al. 2013, Menegaux et al. 2013, Rabstein et al. 2013, Akerstedt et al. 2015, Papantoniou et al. 2015). Meta-analysis studies have also reported a positive association between night work and breast cancer risk (Jia et al. 2013) and that a positive dose-response gradient is observed for breast cancer with increased years of night shift and cumulative night work (Wang et al. 2013).

Although circadian disruption is prominently linked to breast cancer tumorigenesis through epidemiological studies, the molecular mechanisms and NRs involved are still largely unknown, with most published studies focusing on the ESR1 as a link between the circadian system and breast cancer development. Many studies suggest that lowered melatonin level due to exposure to night light contributes toward breast cancer development and drug resistance. Melatonin is thought to exert its oncostatic effect through multiple mechanisms including antimitosis, anti-angiogenesis, anti-oxidation and regulation of immune response (Viswanathan \& Schernhammer 2009). The oncostatic effect of melatonin in breast cancer is thought be mediated through its anti-estrogenic actions as well as its role in regulating the activity of aromatases, the enzymes responsible for the local biosynthesis of estrogens from androgens (Cos et al. 2006). Recent studies using MCF-7 breast cancer xenografts in mice showed that suppression of melatonin production by dim light exposure at night leads to both tamoxifen (Dauchy et al. 2014) and doxorubicin resistance (Xiang et al. 2015).

In addition to the effect of melatonin, there is evidence linking the core clock genes as well as the REVERBs with breast cancer growth and metastasis. The rhythmic expression of the PER genes are reported to be altered in primary breast tumors (Chen et al. 2005) as well as in breast cancer cell lines (Xiang et al. 2012). A recent study demonstrated the association of the core clock gene BMAL2 in ER breast cancer metastasis (Ha et al. 2016). Furthermore, activation of REV-ERBA and REV-ERBB by a synthetic ligand is anti-proliferative in breast cancer cells.
ESR1 has been shown to be an important regulator linking the circadian system and breast cancer tumorigenesis, acting as a regulator of (as well as being regulated by) the core clock genes. ESR1 appears to participate in a feedback loop involving the clock protein PER2, which was shown to be a tumor suppressor in luminal breast cancer. Although PER2 is E2 inducible, PER2 itself is thought to mediate ESR1 degradation through the proteasome pathway. Suppression of PER2 leads to ESR1 stabilization (Gery et al. 2007). In addition, ESR1 was shown to bind estrogen response elements in the promoter region of $C L O C K$ leading to the upregulation of CLOCK in breast cancer cells. Knockdown of CLOCK attenuated proliferation in breast cancer cells (Xiao et al. 2014). Therefore, CLOCK appears to be an important mediator of the proliferative effect of E2 in breast cancer.

In summary, NRs play important regulatory roles in both the universal and tissue-specific circadian systems. In particular, REV-ERBs and RORs are integral regulators of the universal circadian clock, and various other NRs exhibit circadian expression. Although epidemiological studies have linked circadian disruption and breast cancer tumorigenesis, a lot remains to be learned about the underlying molecular mechanism. Lowered melatonin due to night light exposure is thought to play a role and there is evidence supporting the involvement of ESR1 as an integral regulator linking circadian regulation and breast cancer development.

\section{Regulation of energy metabolism}

As the initial observation by Warburg that proliferating tumor cells converted the majority of their glucose to lactate even in oxygen-rich condition and his hypothesis that altered metabolism is a characteristic of cancer cells, metabolic reprogramming has now attained cancer hallmark status (Ward \& Thompson 2012). Specifically, the Warburg effect describes a shift toward aerobic glycolysis in preference to oxidative phosphorylation as the major means of ATP generation in cancer cells, even in oxygen-rich conditions. Although aerobic glycolysis is not as efficient as oxidative phosphorylation (yielding only $2 \mathrm{~mol}$ of ATP/mole of glucose instead of $36 \mathrm{~mol} \mathrm{ATP/}$ mole of glucose), it has certain benefits for tumor cells. Glycolysis results in more rapid production of ATP, fatty acids and nucleotides that are needed by proliferating tumor cells that need to double their biomass to divide. Furthermore, the generation of lactic acid promotes a tumor microenvironment that is protective against http://jme.endocrinology-journals.org DOI: 10.1530/JME-16-0082
() 2017 Society for Endocrinology Printed in Great Britain
Published by Bioscientifica Ltd 
immune attack (Calcinotto et al. 2012). It has also been suggested through glucose flux modeling that accumulation of glucose actually promotes aerobic glycosis in preference to oxidative phosphorylation (Vazquez et al. 2010); hence, glucose flux can potentially act as a trigger for the Warburg effect.

It has emerged that NRs are centrally placed in many of the pathways controlling energy metabolism, from regulating glucose transporters to controlling the downstream pathways involved in glucose metabolism. Their altered expression in breast cancers is potentially intimately linked to the metabolic reprogramming of the tumors cells. Here, we review our current understanding of the roles of NRs in breast cancer cellular metabolism.

REV-ERBs In addition and related to their prominent roles in circadian regulation, REV-ERBs are recognized as integrators of circadian regulation and metabolic pathways (Cho et al. 2012, Gerhart-Hines \& Lazar 2015). A recent study looking at genome-wide location of REVERBA in various tissues reported different mechanisms of gene regulation employed by REV-ERBA with regard to circadian control and metabolic control. Although circadian regulation requires direct DNA binding of REV-ERBA to its cognate site, metabolic control involves the recruitment of HDAC3, which is tethered by cell type-specific transcription factors (Zhang et al. 2015). A recent publication suggests that although REV-ERBA has a dominant role in normal cells, REV-ERBB seems to be the dominant isoform controlling both circadian rhythm and metabolic pathways in cancer cells, including breast cancer (De Mei et al. 2015). REV-ERBB is significantly more abundant in cancer cells compared to REV-ERBA, whereas the opposite is observed in normal cells. Knockdown of REV-ERBB resulted in the enhanced expression of both circadian and metabolic target genes in breast cancer cells while knockdown of REV-ERBA had no effect. However, ERBB2-positive breast cancer cells appear to have higher expression of REV-ERBA compared to ERBB2negative cells, consistent with a previous study reporting co-expression of REV-ERBA and ERBB2 and pro-survival function of REV-ERBA in ERBB2-positive breast cancer cells (Kourtidis et al. 2010). These studies suggest that the two REV-ERB isoforms probably have redundant functions in transcriptional regulation, and functional predominance in a particular cell type depends on the relative expression level of each isoform.

Estrogen-related receptors (ERRs) The estrogenrelated receptors (ESRRA/NR3B1, ESRRB/NR3B2 and
ESRRG/NR3B3) have become recognized as the master regulators of energy metabolism in multiple tissues with high energy demand (Giguere 2008, Deblois \& Giguere 2013). Both ESRRA and ESRRG have dominant roles in maintaining energy homeostasis through the regulation of metabolic gene networks. In the heart, ESRRA and ESRRG co-operate to control genes involved in uptake of energy substrates, production and transport of ATP across the mitochondrial membrane (Alaynick et al. 2007, Dufour et al. 2007). ESRRA was reported to co-operate with the peroxisome proliferator-activated receptorgamma coactivator alpha gene (PGC-1 $\alpha$ ) in a doublepositive feedback loop to regulate the expression of many oxidative phosphorylation genes in mouse myoblast cells (Mootha et al. 2004). In the liver, ESRRA was reported to co-operate with PROX1 and BMAL1 to regulate circadian and metabolic gene networks (Dufour et al. 2011). Together, the three ERR isoforms recognize the proximal regulatory regions of 705 genes involved in all aspects of mitochondrial biogenesis and function (Eichner \& Giguere 2011).

In the breast, ESRRA and ESRRG are associated with distinct survival outcomes (Ariazi et al. 2002). Although ESRRA is associated with increased recurrence and poor outcome (Thewes et al. 2015), ESRRG expression is correlated with ESR1 and ERBB4, which are markers of favorable outcome (Ariazi et al. 2002). It has been suggested that ESRRA and ESRRG have opposite roles in the regulation of metabolic reprogramming of breast cancer cells (Deblois \& Giguere 2013). Although ESRRA promotes aerobic glycolysis through the upregulation of enzymes that regulate the glycolysis pathway (Cai et al. 2013), ESRRG is thought to sustain oxidative phosphorylation through regulation of genes that control the tricarboxylic acid cycle (Eichner et al. 2010). However, metabolic reprogramming by ERRs in breast cancers probably involves much greater complexity, given that overexpression of ESRRG also leads to increased expression of enzymes in the glycolytic pathways (Cai et al. 2013) and that ESRRA and ESRRG readily form heterodimers and bind to regulatory regions of many shared target genes (Dufour et al. 2007).

ESRRs also interact with oncogenes that are known modulators of metabolic pathways such as MYC, HIF and ERBB2. Many genes in the glycolytic pathways are regulated by MYC. ESRRA was found to participate in a complex with MYC to co-regulate glycolytic genes (Cai et al. 2013). HIF directly activates glucose transporters and the majority of genes in the glycolytic pathways. All three ESRR isoforms were identified as coactivating

Published by Bioscientifica Ltd. 
factors of HIF and to enhance HIF-induced glycolytic and angiogenic gene expression in hypoxic condition (Ao et al. 2008). ESRRA also regulates the expression of ERRB2 (Deblois et al. 2010), which was reported to translocate to the mitochondria of tumor cells and regulate energy metabolism. Overexpression of mitochondrial ERBB2 decreases mitochondrial electron transport chain activity and enhances cellular glycolysis (Ding et al. 2012). In addition, ERBB2 influences the glycolytic phenotype through upregulation of lactate dehydrogenase (Zhao et al. 2009 ) as well as REV-ERBA, an NR that was reported to be involved in glycolysis and fatty acid synthesis in breast cancer cells (Kourtidis et al. 2010).

In summary, the ERRs are prominent regulators of gene networks controlling glycolysis and oxidative phosphorylation in metabolic tissues. In the breast, ESRRA expression is associated with poor outcome and appears to be involved in reprogramming the cell to favor aerobic glycolysis, a metabolic state characteristic of cancer cells. ESRRG, on the other hand, is associated with better outcome and is involved in maintaining oxidative phosphorylation, a metabolic state characteristic of normal cells. However, given that ESRRA and ESRRG can form heterodimers and readily bind to many shared target genes, the complexity of the mechanisms for controlling their specificity of action is still to be deciphered.

\section{Peroxisome proliferator-activated receptors} (PPARs) PPARs function as heterodimers with the retinoid receptors (RXR) and regulate various genes that are involved in lipid metabolism and energy homeostasis. Through these pathways, PPARs influence various cancer-related cellular processes such as proliferation, differentiation and survival (Michalik et al. 2004). Three PPAR isotypes (PPARA/NR1C1, PPARD/NR1C2 and PPARG/NR1C3) are known, each with unique expression profile and functional roles. The PPARs showed decreased expression in breast cancer compared to normal breast (Muscat et al. 2013). The role of PPARD in breast cancer tumorigenesis is unclear. Although activation of PPARD has been shown to inhibit breast cancer cell line tumorigenicity (Yao et al. 2014), inhibition of PPARD by inverse agonists was reported to inhibit breast cancer cell invasion (Adhikary et al. 2013). PPARG is the best studied of the 3 PPAR subtypes and has been reported to have an anti-proliferative effect on breast cancer cells (Pon et al. 2015) and is associated with better outcomes based on survival analysis of PPARG protein expression level in BC tissue microarrays (Abduljabbar et al. 2015a). The downstream effect of PPARG seems to be dependent on the cell compartment in which PPARG is activated though, with activation in cancer cells resulting in growth inhibition while activation in stromal cells results in growth enhancement of co-injected breast cancer cells (Avena et al. 2013). Recent studies have also suggested an involvement of PPARG and energy metabolism in breast cancer. Firstly, several genes controlling the glycolytic pathways are found to have peroxisome proliferator response element (PPRE) suggesting their regulation by PPARs (Sakharkar et al. 2013). Secondly, overexpression of PPARG in fibroblasts increased the production of L-lactate and mitochondrial dysfunction. In addition, PPARG induces the activation of HIF1A, a transcription factor that promotes glycolysis (Avena et al. 2013).

\section{Control of breast cancer migration and metastasis}

Breast cancer metastasis accounts for the majority of deaths from breast cancer. Early detection and a deeper understanding of the metastatic process are critical to develop therapeutic interventions. Metastasis involves a complex cascade of steps starting with invasion by the primary tumor of the surrounding host tissues, followed by intravasation and dissemination of the tumors cells via the blood or lymphatic system, infiltration and colonization at the distant site. Several factors and pathways are known to influence cancer metastasis including disintegration of cell-to-cell adhesion, proteolytic remodeling of the extracellular matrix, cell motility, evasion of immune and apoptotic signals and angiogenesis. Although substantial information is known about the process of metastasis, the molecular basis of breast cancer metastasis remains poorly understood. NRs, being master regulators of almost every physiological aspect of life, are likely to be intimately involved in the metastasis process. Here, we summarize the current understanding of the roles of various NRs in biological pathways affecting breast cancer metastasis.

Estrogen receptors The estrogen receptors alpha (ESR1) and beta (ESR2) appear to have distinct roles in breast cancer progression and metastasis, with reports of ESR1 signaling enhancing breast cancer cell migration and invasion, whereas ESR2 signaling has the opposite effects.

Emerging evidence suggests that estradiol's positive effect on cell migration and invasion appears to be mediated through ESR1's extranuclear signaling. ESR1 extranuclear signaling is mediated through the PI3K, MAPK and c-Jun N-terminal kinase pathways (Li et al. 2010, Zheng et al. 2011) with the involvement of PELP1 (Chakravarty et al. 2010), focal adhesion kinase (FAK)

Published by Bioscientifica Ltd. 
(Sanchez et al. 2010), c-Src and paxillin (Li et al. 2010) for activation. Downstream activation of the RhoA/ ROCK-2 cascade has also been reported (Giretti et al. 2008, Zheng et al. 2011). Recruitment of the actin-binding protein moesin (Giretti et al. 2008) and phosphorylation of the actin-binding protein ezrin (Zheng et al. 2011) were reported as possible mechanisms through which ESR1 signaling influences the cytoskeletal organization. These E2-mediated signaling pathways induce features of motile cells such as dynamic actin cytoskeleton remodeling and formation of ruffles and filopodia-like structures, which resulted in enhanced motility and migration of breast cancer cells (Chakravarty et al. 2010).

ESR2, on the other hand, has been associated with less invasive and proliferative tumors (Jarvinen et al. 2000, Lazennec et al. 2001). Overexpression of ESR2 leads to reduced cell growth and mobility (Li et al. 2012) and ESR2 was reported to upregulate E-cadherin (Zhou et al. 2015), integrin alpha1, integrin beta1 and enhance the formation of vinculin-containing focal complexes and actin filaments (Lindberg et al. 2010), which consequently strengthens cell adhesion and reduces migration and invasion.

However, ESR2's influence on cell migration is possibly more complex than simply having an anti-migratory and anti-proliferative effect, with contradictory reports of ESR2 having both pro-invasive and pro-migratory effects, especially in specific breast cancer subtypes, due to crosstalk with ESR1 as well as differential effect of different ESR2 variants. ESR2 and PEA3 were reported to co-activate IL-8 resulting in increased invasiveness in ER+ MCF-7 cells (Chen et al. 2011). In inflammatory breast cancer cells, which express both ESR 2 and ESR $1_{36}$ (an ESR1 variant), it was suggested that non-genomic signaling involving ESR $1_{36}$, ESR2 and GPR30 through activation of $\mathrm{p}$-ERK1/2 to have pro-migratory and pro-invasive effect (Ohshiro et al. 2012). Furthermore, expression of an ESR2 variant, ESR2cx in primary tumors, was reported to correlate with higher risk of lymph node metastasis (Rosin et al. 2014). In summary, the effects of estrogen receptor signaling on breast cancer cell metastasis is complex with different isoforms having opposing roles, which is further complicated by divergent effects of subtype variants and crosstalk. The emerging picture is that of ESR1 exerting pro-migratory and pro-invasive effects through extranuclear signaling to regulate cell adhesion and cytoskeletal remodeling while ESR2 exerts the opposite effect through as yet unclear mechanisms.
Progesterone receptors $P G R$ in the human is expressed as two functionally different forms (PGRA and PGRB) arising from alternate promoter activities driving a single gene (Kastner et al. 1990). PGRA and PGRB are equivalently expressed in most normal cells, but commonly their expression becomes deregulated in breast cancer resulting in a predominance of one isoform (usually PGRA) (Graham et al. 1995). This disruption is seen early in disease progression (Mote et al. 2002) and is associated with a poorer response to the anti-estrogen tamoxifen (Mote et al. 2015). A number of studies have demonstrated progestin effects on breast cancer cell adhesion, migration and invasive potential. However, these effects are ligand, PGR isoform and context dependent. In general, progestins acting through nuclear PGR inhibit cell migration and invasiveness (Lin et al. 2000, 2001, McGowan et al. 2004, Carnevale et al. 2007). In cells transfected with PGR, progestin treatment increases actin stress fibers and focal contacts, consistent with increased adhesion and decreased migration (Lin et al. 2000, 2001). Invasion of T-47D breast cancer cells, expressing equivalent PGR isoform levels, is inhibited by progestins (McGowan et al. 2004). However, predominance of PGRA results in an altered progestin response, including increased focal adhesion signaling (Graham et al. 2005), enhanced migration and increased invasion (McGowan et al. 2004), potentially contributing to the poorer outcomes seen in PGRA-predominant breast cancers.

Crosstalk between PGR and cytoplasmic signaling pathways is implicated in breast cancer migration and metastasis. Using a DNA-binding mutant PGR, Carnevale and coworkers (Carnevale et al. 2007) reported that PGR activated cytoplasmic signaling cascades that contributed to breast cancer metastasis. Progestin activation of MAPK, PI3K/Akt and GTPase/RhoA modulated the expression of genes such as urokinase plasminogen activator (uPA), uPA receptor (uPAR), matrix metalloproteases (MMPs), $\beta 1$-integrin and PAI-1 (Carnevale et al. 2007, Fu et al. 2008, Bellance et al. 2013) suggesting a mechanism through which migration is increased by progestins. In addition, progesterone/ progestins also enhance the phosphorylation of focal adhesion kinase (FAK) (Graham et al. 2005, Fu et al. 2008, Bellance et al. 2013), and this is enhanced with PGRA predominance (Graham et al. 2005), promoting the formation and turnover of focal adhesion points and cytoskeletal reorganization involved in cellular motility and influencing breast cancer progression and metastasis (Luo \& Guan 2010).

Published by Bioscientifica Ltd. 
PGR has also been reported to exert ligandindependent effects on breast cancer cell morphology and migration (Jacobsen et al. 2005, Carnevale et al. 2007, Bellance et al. 2013). Un-liganded PGRA was shown to differentially regulate genes involved in cell adhesion and increase adhesiveness and migration in inducible cells expressing just one isoform (Jacobsen et al. 2005). However, in a recent study using bi-inducible MDA-MB-231 cells, un-liganded PGRB but not PGRA increased cell migration via differential effects on focal adhesion signaling (Bellance et al. 2013). Furthermore, it has been demonstrated that extensive ligand-independent action of PGRB are dependent on specific post-translational modifications, particularly phosphorylation, and associated with pro-survival pathways (Daniel et al. 2007, Faivre et al. 2008, Knutson et al. 2012). These findings in the absence of ligand suggest that disrupted PGR isoform expression may have particular importance in the context of post-menopausal breast cancer, where circulating progesterone is low or absent.

In summary, the emerging picture is that the effects of PGR and progesterone on breast cancer metastasis, adhesion and invasion are context dependent and influenced by the relative ratio of PGR isoforms being expressed, the presence of ligands and whether PGR functions as a transcription factor or activator of signaling cascades, but that PGR contributes to increased invasive and metastatic behavior in a number of contexts.

Retinoic acid receptors Several studies demonstrated the anti-proliferative and anti-migratory effect of retinoids on breast cancer cells. Specifically, all-trans retinoid acid (ATRA) was reported to modulate several migration-related proteins such as downregulation of MMP-1, MMP-2, MMP-9, FAK, NF- $\mathrm{B}$ and p-ERK and upregulation of E-cadherin in breast cancer cell lines (Liu et al. 2003, Dutta et al. 2009, 2010). The anti-migratory effect of retinoids on breast cancer cells were shown to be mediated through RARB with treatment of RA or RARB agonist resulting in significantly reduced cell migration while treatment with RARA or RARG agonists did not (Flamini et al. 2014). RARB is the only member of the RARs showing decreased expression in breast cancers (Muscat et al. 2013). RARB showed progressively decreased expression during breast carcinogenesis, with only around $50 \%$ of invasive breast carcinoma expressing RARB (Xu et al. 1997). Transduction of RARB2 resulted in significant reduction in metastasis rate in a mouse xenograft model (Treuting et al. 2002). Together, these findings highlight that RARB is necessary for mediating the anti-migratory effect of retinoic acid through modulation of expression of genes involved in cell migration.

Estrogen-related receptors Aside from their prominent role as master regulators of energy metabolism, the ERRs have been reported to influence the migratory potential of breast cancer cells. Knockdown of ESRRA dramatically decreased the migratory potential of breast cancer cells (Stein et al. 2008), later determined to be mediated through VEGF (Stein et al. 2009) and WNT11 (Dwyer et al. 2010) signaling pathways, which are known regulators of angiogenesis. Inactivation of ESRRA also resulted in impaired directional migration of breast cancer cells, mediated through enhanced stability of RHOA, a protein involved in controlling oriented cellular migration (Sailland et al. 2014). ESRRA itself was found to be a target of miR-137 (Zhao et al. 2012). Therefore, consistent with reports of its association with poor prognosis, activation of ESRRA has a pro-migratory effect on breast cancer cells. By contrast, and consistent with its association with better breast cancer outcome, ESRRG was reported to promote mesenchymal-to-epithelial transition and decrease breast cancer cell invasiveness through activation of E-cadherin (Tiraby et al. 2011). Therefore, similar to their opposing roles in metabolic reprogramming, ESSRA and ESSRG display opposing influences on breast cancer cell migration and invasiveness.

NUR77 NUR77 (NR4A1) expression is elevated in both ER+ and ER- breast tumors (Muscat et al. 2013), and NUR77 expression is correlated with decreased relapsefree survival in breast cancer (Alexopoulou et al. 2010), consistent with reports of its pro-oncogenic role in breast cancer (Hedrick et al. 2015). Contradictory to a previous report of NUR77 having anti-migratory effects in MCF-10A breast cancer cells, recently, NUR77 expression was shown to have pro-migratory effects through activation of TGF-beta signaling (Zhou et al. 2014), which is known to have an important role in breast cancer metastasis (Moore et al. 2008, Kohn et al. 2012, Luwor et al. 2015).

COUP-TF1 and COUP-TF2 COUP-TFs are orphan nuclear receptors primarily known for their important roles in organogenesis including angiogenesis, cellular growth, differentiation and migration (Boudot et al. 2011). Their roles in breast cancer growth and progression have recently been highlighted. Both COUP-TF1 and COUP-TF2 expression are lower in breast tumors

Published by Bioscientifica Ltd 
compared to normal breast tissue (Muscat et al. 2013). COUP-TF1 expression was reported to be higher in dedifferentiated breast cancer cells and correlated with low expression of E-cadherin and expression of vimentin (Le Dily et al. 2008). Overexpression of COUP-TF1 in MCF-7 cells results in a decrease in CXCL12 and increase in CXCR4 expression, mediated by EGF signaling, and leads to enhanced motility and invasiveness of MCF-7 breast cancer cells (Le Dily et al. 2008, Boudot et al. 2014). CXCL12 expression in primary tumors has recently been reported to drive breast cancer metastasis (Ray et al. 2015). The other COUP-TF member, COUP-TF2, may also have a role in breast cancer cell migration and invasion with a report that transfection of COUP-TF2 into MDA-MB-231 resulted in increased migration and invasion of these cells (Navab et al. 2004). Together these findings suggest a potential involvement of COUP-TFs in epithelialto-mesenchymal transition and migration of breast cancer cells.

\section{Concluding remarks}

Advances in genomic technologies have enabled more integrated insights into the roles of NRs in breast cancer biology: their expression, genomic distribution, mechanisms of action, as well as the complexity of their functional interactions. Expression profiling studies have shown that many NRs, in addition to ESR1 and PGR, are expressed and are potentially functional in breast cancer. Cistromic profiling studies highlight the complexity of NR transcriptional regulation, how multiple NRs often work together as well as with other coregulators and the chromatin landscape to fine tune the cell-specific expression of target genes, and how changes in the gene regulatory programs of NR are associated with the tumor state. Finally, it is evident that in addition to regulating proliferation and apoptosis, NRs are critical regulators of a diverse range of other cancer-associated biological processes including the circadian clock, metabolic reprogramming and migration and metastasis.

\section{Declaration of interest}

The authors declare that there is no conflict of interest that could be perceived as prejudicing the impartiality of the research reported.

\section{Funding}

A Collaborative Program Grant from the National Breast Cancer Foundation Australia and a UPA Scholarship from the University of Sydney supported this work.

\section{References}

Abduljabbar R, Al-Kaabi MM, Negm OH, Jerjees D, Muftah AA, Mukherjee A, Lai CF, Buluwela L, Ali S, Tighe PJ, et al. 2015a Prognostic and biological significance of peroxisome proliferatoractivated receptor-gamma in luminal breast cancer. Breast Cancer Research and Treatment 150 511-522. (doi:10.1007/s10549-0153348-9)

Abduljabbar R, Negm OH, Lai CF, Jerjees DA, Al-Kaabi M, Hamed MR, Tighe PJ, Buluwela L, Mukherjee A, Green AR, et al. 2015b Clinical and biological significance of glucocorticoid receptor (GR) expression in breast cancer. Breast Cancer Research and Treatment 150 335-346. (doi:10.1007/s10549-015-3335-1)

Adhikary T, Brandt DT, Kaddatz K, Stockert J, Naruhn S, Meissner W, Finkernagel F, Obert J, Lieber S, Scharfe M, et al. 2013 Inverse PPARbeta/delta agonists suppress oncogenic signaling to the ANGPTL4 gene and inhibit cancer cell invasion. Oncogene $\mathbf{3 2}$ 5241-5252. (doi:10.1038/onc.2012.549)

Akashi M \& Takumi T 2005 The orphan nuclear receptor RORalpha regulates circadian transcription of the mammalian core-clock Bmal1. Nature Structural and Molecular Biology 12 441-448. (doi:10.1038/nsmb925)

Akerstedt T, Knutsson A, Narusyte J, Svedberg P, Kecklund G \& Alexanderson K 2015 Night work and breast cancer in women: a Swedish cohort study. BMJ Open 5 e008127. (doi:10.1136/ bmjopen-2015-008127)

Akhtar RA, Reddy AB, Maywood ES, Clayton JD, King VM, Smith AG, Gant TW, Hastings MH \& Kyriacou CP 2002 Circadian cycling of the mouse liver transcriptome, as revealed by cDNA microarray, is driven by the suprachiasmatic nucleus. Current Biology 12 540-550. (doi:10.1016/S0960-9822(02)00759-5)

Alaynick WA, Kondo RP, Xie W, He W, Dufour CR, Downes M, Jonker JW, Giles W, Naviaux RK, Giguere V, et al. 2007 ERRgamma directs and maintains the transition to oxidative metabolism in the postnatal heart. Cell Metabolism 6 13-24. (doi:10.1016/j. cmet.2007.06.007)

Alexopoulou AN, Leao M, Caballero OL, Da Silva L, Reid L, Lakhani SR, Simpson AJ, Marshall JF, Neville AM \& Jat PS 2010 Dissecting the transcriptional networks underlying breast cancer: NR4A1 reduces the migration of normal and breast cancer cell lines. Breast Cancer Research 12 R51. (doi:10.1186/bcr2610)

Ao A, Wang H, Kamarajugadda S \& Lu J 2008 Involvement of estrogenrelated receptors in transcriptional response to hypoxia and growth of solid tumors. PNAS 105 7821-7826. (doi:10.1073/ pnas.0711677105)

Ariazi EA, Clark GM \& Mertz JE 2002 Estrogen-related receptor alpha and estrogen-related receptor gamma associate with unfavorable and favorable biomarkers, respectively, in human breast cancer. Cancer Research 62 6510-6518.

Auwerx J, Baulieu E, Beato M, Becker-Andre M, Burbach PH, Camerino G, Chambon P, Cooney A, Dejean A, Dreyer C, et al. 1999 A unified nomenclature system for the nuclear receptor superfamily. Cell 97 161-163. (doi:10.1016/S0092-8674(00)80726-6)

Avena P, Anselmo W, Whitaker-Menezes D, Wang C, Pestell RG, Lamb RS, Hulit J, Casaburi I, Ando S, Martinez-Outschoorn UE, et al. 2013 Compartment-specific activation of PPARgamma governs breast cancer tumor growth, via metabolic reprogramming and symbiosis. Cell Cycle 12 1360-1370. (doi:10.4161/cc.24289)

Ballare C, Castellano G, Gaveglia L, Althammer S, Gonzalez-Vallinas J, Eyras E, Le Dily F, Zaurin R, Soronellas D, Vicent GP, et al. 2013 Nucleosome-driven transcription factor binding and gene regulation. Molecular Cell 49 67-79. (doi:10.1016/j.molcel.2012.10.019)

Barton VN, D'Amato NC, Gordon MA, Christenson JL, Elias A \& Richer JK 2015 Androgen receptor biology in triple negative breast cancer: a case for classification as AR+ or quadruple negative disease. Hormones and Cancer 6 206-213. (doi:10.1007/s12672-015-0232-3)

Published by Bioscientifica Ltd. 
Bechtold DA, Gibbs JE \& Loudon AS 2010 Circadian dysfunction in disease. Trends in Pharmacological Sciences 31 191-198. (doi:10.1016/j. tips.2010.01.002)

Bellance C, Khan JA, Meduri G, Guiochon-Mantel A, Lombes M \& Loosfelt H 2013 Progesterone receptor isoforms PRA and PRB differentially contribute to breast cancer cell migration through interaction with focal adhesion kinase complexes. Molecular Biology of the Cell 24 1363-1374. (doi:10.1091/mbc.E12-11-0807)

Biddie SC, John S, Sabo PJ, Thurman RE, Johnson TA, Schiltz RL, Miranda TB, Sung MH, Trump S, Lightman SL, et al. 2011 Transcription factor AP1 potentiates chromatin accessibility and glucocorticoid receptor binding. Molecular Cell 43 145-155. (doi:10.1016/j.molcel.2011.06.016)

Bookout AL, Jeong Y, Downes M, Yu RT, Evans RM \& Mangelsdorf DJ 2006 Anatomical profiling of nuclear receptor expression reveals a hierarchical transcriptional network. Cell 126 789-799. (doi:10.1016/j.cell.2006.06.049)

Boudot A, Le Dily F \& Pakdel F 2011 Involvement of COUP-TFs in cancer progression. Cancers 3 700-715. (doi:10.3390/cancers3010700)

Boudot A, Kerdivel G, Lecomte S, Flouriot G, Desille M, Godey F, Leveque J, Tas P, Le Drean Y \& Pakdel F 2014 COUP-TFI modifies CXCL12 and CXCR4 expression by activating EGF signaling and stimulates breast cancer cell migration. BMC Cancer 14407. (doi:10.1186/1471-2407-14-407)

Cai Q, Lin T, Kamarajugadda S \& Lu J 2013 Regulation of glycolysis and the Warburg effect by estrogen-related receptors. Oncogene 32 2079-2086. (doi:10.1038/onc.2012.221)

Calcinotto A, Filipazzi P, Grioni M, Iero M, De Milito A, Ricupito A, Cova A, Canese R, Jachetti E, Rossetti M, et al. 2012 Modulation of microenvironment acidity reverses anergy in human and murine tumor-infiltrating T lymphocytes. Cancer Research 72 2746-2756. (doi:10.1158/0008-5472.CAN-11-1272)

Carnevale RP, Proietti CJ, Salatino M, Urtreger A, Peluffo G, Edwards DP Boonyaratanakornkit V, Charreau EH, Bal de Kier Joffe E, Schillaci R, et al. 2007 Progestin effects on breast cancer cell proliferation, proteases activation, and in vivo development of metastatic phenotype all depend on progesterone receptor capacity to activate cytoplasmic signaling pathways. Molecular Endocrinology 21 1335-1358. (doi:10.1210/me.2006-0304)

Carroll JS, Meyer CA, Song J, Li W, Geistlinger TR, Eeckhoute J, Brodsky AS, Keeton EK, Fertuck KC, Hall GF, et al. 2006 Genomewide analysis of estrogen receptor binding sites. Nature Genetics $\mathbf{3 8}$ 1289-1297. (doi:10.1038/ng1901)

Chakravarty D, Nair SS, Santhamma B, Nair BC, Wang L, Bandyopadhyay A, Agyin JK, Brann D, Sun LZ, Yeh IT, et al. 2010 Extranuclear functions of ER impact invasive migration and metastasis by breast cancer cells. Cancer Research 70 4092-4101. (doi:10.1158/0008-5472.CAN-09-3834)

Chen ST, Choo KB, Hou MF, Yeh KT, Kuo SJ \& Chang JG 2005 Deregulated expression of the PER1, PER2 and PER3 genes in breast cancers. Carcinogenesis 26 1241-1246. (doi:10.1093/carcin/bgi075)

Chen Y, Chen L, Li JY, Mukaida N, Wang Q, Yang C, Yin WJ, Zeng XH, Jin W \& Shao ZM 2011 ERbeta and PEA3 co-activate IL-8 expression and promote the invasion of breast cancer cells. Cancer Biology and Therapy 11 497-511. (doi:10.4161/cbt.11.5.14667)

Cho H, Zhao X, Hatori M, Yu RT, Barish GD, Lam MT, Chong LW, DiTacchio L, Atkins AR, Glass CK, et al. 2012 Regulation of circadian behaviour and metabolism by REV-ERB-alpha and REV-ERB-beta. Nature 485 123-127. (doi:10.1038/nature11048)

Cirillo LA, Lin FR, Cuesta I, Friedman D, Jarnik M \& Zaret KS 2002 Opening of compacted chromatin by early developmental transcription factors HNF3 (FoxA) and GATA-4. Molecular Cell 9 279-289. (doi:10.1016/S1097-2765(02)00459-8)

Ciupek A, Rechoum Y, Gu G, Gelsomino L, Beyer AR, Brusco L, Covington KR, Tsimelzon A \& Fuqua SA 2015 Androgen receptor promotes tamoxifen agonist activity by activation of EGFR in
ERalpha-positive breast cancer. Breast Cancer Research and Treatment 154 225-237. (doi:10.1007/s10549-015-3609-7)

Clarke CL \& Graham JD 2012 Non-overlapping progesterone receptor cistromes contribute to cell-specific transcriptional outcomes. PLoS ONE 7 e35859. (doi:10.1371/journal.pone.0035859)

Cochrane DR, Bernales S, Jacobsen BM, Cittelly DM, Howe EN, D'Amato NC, Spoelstra NS, Edgerton SM, Jean A, Guerrero J, et al. 2014 Role of the androgen receptor in breast cancer and preclinical analysis of enzalutamide. Breast Cancer Research 16 R7. (doi:10.1186/bcr3599)

Conway-Campbell BL, Sarabdjitsingh RA, McKenna MA, Pooley JR, Kershaw YM, Meijer OC, De Kloet ER \& Lightman SL 2010 Glucocorticoid ultradian rhythmicity directs cyclical gene pulsing of the clock gene period 1 in rat hippocampus. Journal of Neuroendocrinology 22 1093-1100. (doi:10.1111/j.1365-2826.2010.02051.x)

Conzen SD 2008 Nuclear receptors and breast cancer. Molecular Endocrinology 22 2215-2228. (doi:10.1210/me.2007-0421)

Cordera F \& Jordan VC 2006 Steroid receptors and their role in the biology and control of breast cancer growth. Seminars in Oncology 33 631-641.

Cos S, Gonzalez A, Martinez-Campa C, Mediavilla MD, AlonsoGonzalez C \& Sanchez-Barcelo EJ 2006 Estrogen-signaling pathway: a link between breast cancer and melatonin oncostatic actions. Cancer Detection and Prevention 30 118-128. (doi:10.1016/j.cdp.2006.03.002)

D'Amato NC, Jacobsen BM, Cochrane DR, Spoelstra NS, Babbs BL, Elias A \& Richer JK 2015 Inhibiting androgen receptor nuclear localization decreases estrogen receptor (ER) activity and tumor growth in ER plus breast cancer. Cancer Research 75 (9 Suppl) abstract P3-04-06. (doi:10.1016/j.cdp.2006.03.002)

Daniel AR, Faivre EJ \& Lange CA 2007 Phosphorylation-dependent antagonism of sumoylation derepresses progesterone receptor action in breast cancer cells. Molecular Endocrinology 21 2890-2906. (doi:10.1210/me.2007-0248)

Daniel AR, Gaviglio AL, Knutson TP, Ostrander JH, D'Assoro AB, Ravindranathan P, Peng Y, Raj GV, Yee D \& Lange CA 2015 Progesterone receptor-B enhances estrogen responsiveness of breast cancer cells via scaffolding PELP1- and estrogen receptor-containing transcription complexes. Oncogene 34 506-515. (doi:10.1038/ onc.2013.579)

Dauchy RT, Xiang S, Mao L, Brimer S, Wren MA, Yuan L, Anbalagan M, Hauch A, Frasch T, Rowan BG, et al. 2014 Circadian and melatonin disruption by exposure to light at night drives intrinsic resistance to tamoxifen therapy in breast cancer. Cancer Research 74 4099-4110. (doi:10.1158/0008-5472.CAN-13-3156)

De Mei C, Ercolani L, Parodi C, Veronesi M, Lo Vecchio C, Bottegoni G, Torrente E, Scarpelli R, Marotta R, Ruffili R, et al. 2015 Dual inhibition of REV-ERBbeta and autophagy as a novel pharmacological approach to induce cytotoxicity in cancer cells. Oncogene 34 2597-2608. (doi:10.1038/onc.2014.203)

Deblois G \& Giguere V 2013 Oestrogen-related receptors in breast cancer: control of cellular metabolism and beyond. Nature Reviews Cancer 13 27-36. (doi:10.1038/nrc3396)

Deblois G, Chahrour G, Perry MC, Sylvain-Drolet G, Muller WJ \& Giguere V 2010 Transcriptional control of the ERBB2 amplicon by ERRalpha and PGC-1beta promotes mammary gland tumorigenesis. Cancer Research 70 10277-10287. (doi:10.1158/0008-5472.CAN-102840)

Ding Y, Liu Z, Desai S, Zhao Y, Liu H, Pannell LK, Yi H, Wright ER, Owen LB, Dean-Colomb W, et al. 2012 Receptor tyrosine kinase ErbB2 translocates into mitochondria and regulates cellular metabolism. Nature Communications 3 1271. (doi:10.1038/ncomms2236)

Dixon JM 2014 Endocrine resistance in breast cancer. New Journal of Science 2014 1-27.

Doan TB, Eriksson NA, Graham D, Funder JW, Simpson ER, Kuczek ES, Clyne C, Leedman PJ, Tilley WD, Fuller PJ, et al. 2014 Breast cancer http://jme.endocrinology-journals.org

DOI: 10.1530/JME-16-0082
() 2017 Society for Endocrinology Printed in Great Britain
Published by Bioscientifica Ltd 
prognosis predicted by nuclear receptor-coregulator networks. Molecular Oncology 8 998-1013. (doi:10.1016/j.molonc.2014.03.017)

Dufour CR, Wilson BJ, Huss JM, Kelly DP, Alaynick WA, Downes M, Evans RM, Blanchette M \& Giguere V 2007 Genome-wide orchestration of cardiac functions by the orphan nuclear receptors ERRalpha and gamma. Cell Metabolism 5 345-356. (doi:10.1016/j. cmet.2007.03.007)

Dufour CR, Levasseur MP, Pham NH, Eichner LJ, Wilson BJ, CharestMarcotte A, Duguay D, Poirier-Heon JF, Cermakian N \& Giguere V 2011 Genomic convergence among ERRalpha, PROX1, and BMAL1 in the control of metabolic clock outputs. PLoS Genetics 7 e1002143. (doi:10.1371/journal.pgen.1002143)

Dutta A, Sen T, Banerii A, Das S \& Chatterjee A 2009 Studies on multifunctional effect of all-trans retinoic acid (ATRA) on matrix metalloproteinase-2 (MMP-2) and its regulatory molecules in human breast cancer cells (MCF-7). Journal of Oncology 2009627840.

Dutta A, Sen T \& Chatterjee A 2010 All-trans retinoic acid (ATRA) downregulates MMP-9 by modulating its regulatory molecules. Cell Adhesion and Migration 4 409-418. (doi:10.4161/cam.4.3.11682)

Dwyer MA, Joseph JD, Wade HE, Eaton ML, Kunder RS, Kazmin D, Chang CY \& McDonnell DP 2010 WNT11 expression is induced by estrogen-related receptor alpha and beta-catenin and acts in an autocrine manner to increase cancer cell migration. Cancer Research 70 9298-9308. (doi:10.1158/0008-5472.CAN-10-0226)

Early Breast Cancer Trialists' Collaborative Group (EBCTCG) 2005 Effects of chemotherapy and hormonal therapy for early breast cancer on recurrence and 15-year survival: an overview of the randomised trials. Lancet 365 1687-1717. (doi:10.1016/s0140-6736(05)66544-0)

Eichner LJ \& Giguere V 2011 Estrogen related receptors (ERRs): a new dawn in transcriptional control of mitochondrial gene networks. Mitochondrion 11 544-552. (doi:10.1016/j.mito.2011.03.121)

Eichner LJ, Perry MC, Dufour CR, Bertos N, Park M, St-Pierre J \& Giguere V 2010 miR-378(*) mediates metabolic shift in breast cancer cells via the PGC-1beta/ERRgamma transcriptional pathway. Cell Metabolism 12 352-361. (doi:10.1016/j.cmet.2010.09.002)

ENCODE Project Consortium 2012 An integrated encyclopedia of DNA elements in the human genome. Nature 489 57-74. (doi:10.1038/ nature11247)

Evans RM \& Mangelsdorf DJ 2014 Nuclear receptors, RXR, and the big bang. Cell 157 255-266. (doi:10.1016/j.cell.2014.03.012)

Faivre EJ, Daniel AR, Hillard CJ \& Lange CA 2008 Progesterone receptor rapid signaling mediates serine 345 phosphorylation and tethering to specificity protein 1 transcription factors. Molecular Endocrinology 22 823-837. (doi:10.1210/me.2007-0437)

Ferlay J, Soerjomataram I, Dikshit R, Eser S, Mathers C, Rebelo M, Parkin DM, Forman D \& Bray F 2015 Cancer incidence and mortality worldwide: sources, methods and major patterns in GLOBOCAN 2012. International Journal of Cancer 136 E359-E386. (doi:10.1002/ ijc.29210)

Fioretti FM, Sita-Lumsden A, Bevan CL \& Brooke GN 2014 Revising the role of the androgen receptor in breast cancer. Journal of Molecular Endocrinology 52 R257-R265. (doi:10.1530/JME-14-0030)

Flamini MI, Gauna GV, Sottile ML, Nadin BS, Sanchez AM \& VargasRoig LM 2014 Retinoic acid reduces migration of human breast cancer cells: role of retinoic acid receptor beta. Journal of Cellular and Molecular Medicine 18 1113-1123. (doi:10.1111/jcmm.12256)

Fontana JA, Nervi C, Shao ZM \& Jetten AM 1992 Retinoid antagonism of estrogen-responsive transforming growth factor alpha and pS2 gene expression in breast carcinoma cells. Cancer Research $\mathbf{5 2}$ 3938-3945.

Fu X-D, Giretti MS, Baldacci C, Garibaldi S, Flamini M, Sanchez AM, Gadducci A, Genazzani AR \& Simoncini T 2008 Extra-nuclear signaling of progesterone receptor to breast cancer cell movement and invasion through the actin cytoskeleton. PLOS ONE $\mathbf{3}$ e2790. (doi:10.1371/journal.pone.0002790)
Gerhart-Hines Z \& Lazar MA 2015 Rev-erb and the circadian transcriptional regulation of metabolism. Diabetes Obesity and Metabolism 17 12-16. (doi:10.1111/dom.12510)

Germain P, Staels B, Dacquet C, Spedding M \& Laudet V 2006 Overview of nomenclature of nuclear receptors. Pharmacological Reviews $\mathbf{5 8}$ 685-704. (doi:10.1124/pr.58.4.2)

Gerstein MB, Kundaje A, Hariharan M, Landt SG, Yan KK, Cheng C, Mu XJ, Khurana E, Rozowsky J, Alexander R, et al. 2012 Architecture of the human regulatory network derived from ENCODE data. Nature 489 91-100. (doi:10.1038/nature11245)

Gertz J, Savic D, Varley KE, Partridge EC, Safi A, Jain P, Cooper GM, Reddy TE, Crawford GE \& Myers RM 2013 Distinct properties of celltype-specific and shared transcription factor binding sites. Molecular Cell 52 25-36. (doi:10.1016/j.molcel.2013.08.037)

Gery S, Virk RK, Chumakov K, Yu A \& Koeffler HP 2007 The clock gene Per2 links the circadian system to the estrogen receptor. Oncogene 26 7916-7920. (doi:10.1038/sj.onc.1210585)

Giguere V 2008 Transcriptional control of energy homeostasis by the estrogen-related receptors. Endocrine Reviews 29 677-696. (doi:10.1210/er.2008-0017)

Giguere V, Hollenberg SM, Rosenfeld MG \& Evans RM 1986 Functional domains of the human glucocorticoid receptor. Cell 46 645-652. (doi:10.1016/0092-8674(86)90339-9)

Giretti MS, Fu X-D, De Rosa G, Sarotto I, Baldacci C, Garibaldi S, Mannella P, Biglia N, Sismondi P, Genazzani AR, et al. 2008 Extranuclear signalling of estrogen receptor to breast cancer cytoskeletal remodelling, migration and invasion. PLOS ONE 3 e2238. (doi:10.1371/journal.pone.0002238)

Graham JD, Yeates C, Balleine RL, Harvey SS, Milliken JS, Bilous AM \& Clarke CL 1995 Characterization of progesterone receptor A and B expression in human breast cancer. Cancer Research 55 5063-5068.

Graham JD, Yager ML, Hill HD, Byth K, O’Neill GM \& Clarke CL 2005 Altered progesterone receptor isoform expression remodels progestin responsiveness of breast cancer cells. Molecular Endocrinology 19 2713-2735. (doi:10.1210/me.2005-0126)

Grogg A, Trippel M, Pfaltz K, Ladrach C, Droeser RA, Cihoric N, Salhia B, Zweifel M \& Tapia C 2015 Androgen receptor status is highly conserved during tumor progression of breast cancer. $B M C$ Cancer 15 872. (doi:10.1186/s12885-015-1897-2)

Gronemeyer H, Gustafsson JA \& Laudet V 2004 Principles for modulation of the nuclear receptor superfamily. Nature Reviews Drug Discovery 3 950-964. (doi:10.1038/nrd1551)

Ha NH, Long J, Cai Q, Shu XO \& Hunter KW 2016 The circadian rhythm gene Arntl2 is a metastasis susceptibility gene for estrogen receptor-negative breast cancer. PLoS Genetics 12 e1006267. (doi:10.1371/journal.pgen.1006267)

Hansen J 2001 Increased breast cancer risk among women who work predominantly at night. Epidemiology 12 74-77. (doi:10.1097/00001648-200101000-00013)

Hansen J \& Lassen CF 2012 Nested case-control study of night shift work and breast cancer risk among women in the Danish military. Occupational and Environmental Medicine 69 551-556. (doi:10.1136/ oemed-2011-100240)

Hansen J \& Stevens RG 2012 Case-control study of shift-work and breast cancer risk in Danish nurses: impact of shift systems. European Journal of Cancer 48 1722-1729. (doi:10.1016/j.ejca.2011.07.005)

Hedrick E, Lee SO, Doddapaneni R, Singh M \& Safe S 2015 Nuclear receptor $4 \mathrm{~A} 1$ as a drug target for breast cancer chemotherapy. Endocrine-Related Cancer 22 831-840. (doi:10.1530/ERC-15-0063)

Hilborn E, Gacic J, Fornander T, Nordenskjold B, Stal O \& Jansson A 2016 Androgen receptor expression predicts beneficial tamoxifen response in oestrogen receptor-alpha-negative breast cancer. British Journal of Cancer 114 248-255. (doi:10.1038/bjc.2015.464)

Hu R, Dawood S, Holmes MD, Collins LC, Schnitt SJ, Cole K, Marotti JD, Hankinson SE, Colditz GA \& Tamimi RM 2011 Androgen http://jme.endocrinology-journals.org

DOI: 10.1530/JME-16-0082
() 2017 Society for Endocrinology Printed in Great Britain
Published by Bioscientifica Ltd 
receptor expression and breast cancer survival in postmenopausal women. Clinical Cancer Research 17 1867-1874. (doi:10.1158/10780432.CCR-10-2021)

Hua S, Kittler R \& White KP 2009 Genomic antagonism between retinoic acid and estrogen signaling in breast cancer. Cell 137 1259-1271. (doi:10.1016/j.cell.2009.04.043)

Hudis CA \& Gianni L 2011 Triple-negative breast cancer: an unmet medical need. Oncologist 16 (Supplement 1) 1-11. (doi:10.1634/ theoncologist.2011-S1-01)

Hurtado A, Holmes KA, Ross-Innes CS, Schmidt D \& Carroll JS 2011 FOXA1 is a key determinant of estrogen receptor function and endocrine response. Nature Genetics 43 27-33. (doi:10.1038/ng.730)

Jacobsen BM, Schittone SA, Richer JK \& Horwitz KB 2005 Progesteroneindependent effects of human progesterone receptors (PRs) in estrogen receptor-positive breast cancer: PR isoform-specific gene regulation and tumor biology. Molecular Endocrinology 19 574-587. (doi:10.1210/me.2004-0287)

Jarvinen TA, Pelto-Huikko M, Holli K \& Isola J 2000 Estrogen receptor beta is coexpressed with ERalpha and PR and associated with nodal status, grade, and proliferation rate in breast cancer. American Journal of Pathology 156 29-35. (doi:10.1016/S0002-9440(10)64702-5)

Jia Y, Lu Y, Wu K, Lin Q, Shen W, Zhu M, Huang S \& Chen J 2013 Does night work increase the risk of breast cancer? A systematic review and meta-analysis of epidemiological studies. Cancer Epidemiology $\mathbf{3 7}$ 197-206. (doi:10.1016/j.canep.2013.01.005)

John S, Sabo PJ, Thurman RE, Sung MH, Biddie SC, Johnson TA, Hager GL \& Stamatoyannopoulos JA 2011 Chromatin accessibility pre-determines glucocorticoid receptor binding patterns. Nature Genetics 43 264-268. (doi:10.1038/ng.759)

Karmakar S, Jin Y \& Nagaich AK 2013 Interaction of glucocorticoid receptor (GR) with estrogen receptor (ER) alpha and activator protein 1 (AP1) in dexamethasone-mediated interference of ERalpha activity. Journal of Biological Chemistry 288 24020-24034. (doi:10.1074/jbc. M113.473819)

Kastner P, Krust A, Turcotte B, Stropp U, Tora L, Gronemeyer H \& Chambon P 1990 Two distinct estrogen-regulated promoters generate transcripts encoding the two functionally different human progesterone receptor forms A and B. EMBO Journal 9 1603-1614.

Keeton EK \& Brown M 2003 Coregulator expression and breast cancer: improving the predictive power of estrogen receptor alpha. Clinical Cancer Research 9 1229-1230.

Kininis M, Chen BS, Diehl AG, Isaacs GD, Zhang T, Siepel AC, Clark AG \& Kraus WL 2007 Genomic analyses of transcription factor binding, histone acetylation, and gene expression reveal mechanistically distinct classes of estrogen-regulated promoters. Molecular and Cellular Biology 27 5090-5104. (doi:10.1128/MCB.00083-07)

Kittler R, Zhou J, Hua S, Ma L, Liu Y, Pendleton E, Cheng C, Gerstein M \& White KP 2013 A comprehensive nuclear receptor network for breast cancer cells. Cell Reports 3 538-551. (doi:10.1016/j. celrep.2013.01.004)

Knower KC, Chand AL, Eriksson N, Takagi K, Miki Y, Sasano H, Visvader JE, Lindeman GJ, Funder JW, Fuller PJ, et al. 2013 Distinct nuclear receptor expression in stroma adjacent to breast tumors. Breast Cancer Research and Treatment 142 211-223. (doi:10.1007/s10549013-2716-6)

Knutson TP, Daniel AR, Fan D, Silverstein KA, Covington KR, Fuqua SA \& Lange CA 2012 Phosphorylated and sumoylation-deficient progesterone receptors drive proliferative gene signatures during breast cancer progression. Breast Cancer Research 14 R95. (doi:10.1186/bcr3211)

Knutsson A, Alfredsson L, Karlsson B, Akerstedt T, Fransson EI, Westerholm P \& Westerlund H 2013 Breast cancer among shift workers: results of the WOLF longitudinal cohort study. Scandinavian Journal of Work, Environment and Health 39 170-177. (doi:10.5271/ sjweh.3323)
Kohn EA, Yang YA, Du Z, Nagano Y, Van Schyndle CM, Herrmann MA, Heldman M, Chen JQ, Stuelten CH, Flanders KC, et al. 2012 Biological responses to TGF-beta in the mammary epithelium show a complex dependency on Smad3 gene dosage with important implications for tumor progression. Molecular Cancer Research 10 1389-1399. (doi:10.1158/1541-7786.MCR-12-0136-T)

Kourtidis A, Jain R, Carkner RD, Eifert C, Brosnan MJ \& Conklin DS 2010 An RNA interference screen identifies metabolic regulators NR1D1 and PBP as novel survival factors for breast cancer cells with the ERBB2 signature. Cancer Research 70 1783-1792. (doi:10.1158/0008-5472.CAN-09-1550)

Krishnan AV, Swami S \& Feldman D 2010 Vitamin D and breast cancer: inhibition of estrogen synthesis and signaling. Journal of Steroid Biochemistry and Molecular Biology 121 343-348. (doi:10.1016/j. jsbmb.2010.02.009)

Krum SA, Miranda-Carboni GA, Lupien M, Eeckhoute J, Carroll JS \& Brown M 2008 Unique ER alpha cistromes control cell type-specific gene regulation. Molecular Endocrinology 22 2393-2406. (doi:10.1210/ me.2008-0100)

Kumar V, Green S, Stack G, Berry M, Jin JR \& Chambon P 1987 Functional domains of the human estrogen receptor. Cell $\mathbf{5 1}$ 941-951. (doi:10.1016/0092-8674(87)90581-2)

Kuznetsova T, Wang SY, Rao NA, Mandoli A, Martens JH, Rother N, Aartse A, Groh L, Janssen-Megens EM, Li G, et al. 2015 Glucocorticoid receptor and nuclear factor kappa-b affect threedimensional chromatin organization. Genome Biology 16264. (doi:10.1186/s13059-015-0832-9)

Lai C-F, Flach KD, Alexi X, Fox SP, Ottaviani S, Thiruchelvam PTR, Kyle FJ, Thomas RS, Launchbury R, Hua H, et al. 2013 Co-regulated gene expression by oestrogen receptor alpha and liver receptor homolog-1 is a feature of the oestrogen response in breast cancer cells. Nucleic Acids Research 41 10228-10240. (doi:10.1093/nar/gkt827)

Laudet V \& Gronemeyer H 20022 - DNA recognition by nuclear receptors. In The Nuclear Receptor FactsBook, pp 22-36. Eds V Laudet $\&$ H Gronemeyer. London, UK: Academic Press.

Lazennec G, Bresson D, Lucas A, Chauveau C \& Vignon F 2001 ER beta inhibits proliferation and invasion of breast cancer cells. Endocrinology 142 4120-4130. (doi:10.1210/en.142.9.4120)

Le Dily F, Metivier R, Gueguen MM, Le Peron C, Flouriot G, Tas P \& Pakdel F 2008 COUP-TFI modulates estrogen signaling and influences proliferation, survival and migration of breast cancer cells. Breast Cancer Research and Treatment 110 69-83. (doi:10.1007/s10549007-9693-6)

Li Y, Wang JP, Santen RJ, Kim TH, Park H, Fan P \& Yue W 2010 Estrogen stimulation of cell migration involves multiple signaling pathway interactions. Endocrinology 151 5146-5156. (doi:10.1210/en.20091506)

Li H, Tu Z, An L, Qian Z, Achilefu S \& Gu Y 2012 Inhibitory effects of ERbeta on proliferation, invasion, and tumor formation of MCF-7 breast cancer cells-prognostication for the use of ERbeta-selective therapy. Pharmaceutical Biology 50 839-849. (doi:10.3109/13880209.2 011.637506)

Lin VC, Ng EH, Aw SE, Tan MG, Ng EH \& Bay BH 2000 Progesterone induces focal adhesion in breast cancer cells MDA-MB-231 transfected with progesterone receptor complementary DNA. Molecular Endocrinology 14 348-358. (doi:10.1210/mend.14.3.0426)

Lin VC, Eng AS, Hen NE, Ng EH \& Chowdhury SH 2001 Effect of progesterone on the invasive properties and tumor growth of progesterone receptor-transfected breast cancer cells MDA-MB-231. Clinical Cancer Research 7 2880-2886.

Lin M-L, Patel H, Remenyi J, Banerji CRS, Lai C-F, Periyasamy M, Lombardo Y, Busonero C, Ottaviani S, Passey A, et al. 2015 Expression profiling of nuclear receptors in breast cancer identifies TLX as a mediator of growth and invasion in triple-negative breast cancer. Oncotarget 6 21685-21703. (doi:10.18632/oncotarget.3942) http://jme.endocrinology-journals.org

DOI: 10.1530/JME-16-0082
○ 2017 Society for Endocrinology Printed in Great Britain
Published by Bioscientifica Ltd 
Lindberg K, Strom A, Lock JG, Gustafsson JA, Haldosen LA \& Helguero LA 2010 Expression of estrogen receptor beta increases integrin alpha1 and integrin beta1 levels and enhances adhesion of breast cancer cells. Journal of Cellular Physiology 222 156-167. (doi:10.1002/jcp.21932)

Liu MH \& Cheung E 2014 Estrogen receptor-mediated long-range chromatin interactions and transcription in breast cancer. Molecular and Cellular Endocrinology 382 624-632. (doi:10.1016/j. mce.2013.09.019)

Liu H, Zang C, Fenner MH, Possinger K \& Elstner E 2003 PPARgamma ligands and ATRA inhibit the invasion of human breast cancer cells in vitro. Breast Cancer Research and Treatment 79 63-74. (doi:10.102 3/A:1023366117157)

Lonard DM \& O'Malley BW 2012 Nuclear receptor coregulators: modulators of pathology and therapeutic targets. Nature Reviews Endocrinology 8 598-604. (doi:10.1038/nrendo.2012.100)

Lonard DM, Lanz RB \& O'Malley BW 2007 Nuclear receptor coregulators and human disease. Endocrine Reviews 28 575-587. (doi:10.1210/ er.2007-0012)

Luo M \& Guan JL 2010 Focal adhesion kinase: a prominent determinant in breast cancer initiation, progression and metastasis. Cancer Letters 289 127-139. (doi:10.1016/j.canlet.2009.07.005)

Lupien M, Eeckhoute J, Meyer CA, Wang Q, Zhang Y, Li W, Carroll JS, Liu XS \& Brown M 2008 FoxA1 translates epigenetic signatures into enhancer-driven lineage-specific transcription. Cell 132 958-970. (doi:10.1016/j.cell.2008.01.018)

Lupien M, Eeckhoute J, Meyer CA, Krum SA, Rhodes DR, Liu XS \& Brown M 2009 Coactivator function defines the active estrogen receptor alpha cistrome. Molecular and Cellular Biology 29 3413-3423. (doi:10.1128/МСB.00020-09)

Lupien M, Meyer CA, Bailey ST, Eeckhoute J, Cook J, Westerling T, Zhang X, Carroll JS, Rhodes DR, Liu XS, et al. 2010 Growth factor stimulation induces a distinct ER(alpha) cistrome underlying breast cancer endocrine resistance. Genes and Development 24 2219-2227. (doi:10.1101/gad.1944810)

Luwor RB, Hakmana D, Iaria J, Nheu TV, Simpson RJ \& Zhu HJ 2015 Single live cell TGF-beta signalling imaging: breast cancer cell motility and migration is driven by sub-populations of cells with dynamic TGF-beta-Smad3 activity. Molecular Cancer 1450. (doi:10.1186/s12943-015-0309-1)

Malovannaya A, Lanz RB, Jung SY, Bulynko Y, Le NT, Chan DW, Ding C, Shi Y, Yucer N, Krenciute G, et al. 2011 Analysis of the human endogenous coregulator complexome. Cell 145 787-799. (doi:10.1016/j.cell.2011.05.006)

Mangelsdorf DJ, Thummel C, Beato M, Herrlich P, Schutz G, Umesono K, Blumberg B, Kastner P, Mark M, Chambon P, et al. 1995 The nuclear receptor superfamily: the second decade. Cell 83 835839. (doi:10.1016/0092-8674(95)90199-X)

McGowan EM, Saad S, Bendall LJ, Bradstock KF \& Clarke CL 2004 Effect of progesterone receptor a predominance on breast cancer cell migration into bone marrow fibroblasts. Breast Cancer Research and Treatment 83 211-220. (doi:10.1023/B:BREA.0000014041.58977.80)

McKenna NJ \& O'Malley BW 2002 Combinatorial control of gene expression by nuclear receptors and coregulators. Cell 108 465-474. (doi:10.1016/S0092-8674(02)00641-4)

McKenna NJ \& O'Malley BW 2010 SnapShot: nuclear receptors I. Cell 142 822-822.e821. (doi:10.1016/j.cell.2010.08.026)

Mehta RG, Peng X, Alimirah F, Murillo G \& Mehta R 2013 Vitamin D and breast cancer: emerging concepts. Cancer Letters 334 95-100. (doi:10.1016/j.canlet.2012.10.034)

Menegaux F, Truong T, Anger A, Cordina-Duverger E, Lamkarkach F, Arveux P, Kerbrat P, Fevotte J \& Guenel P 2013 Night work and breast cancer: a population-based case-control study in France (the CECILE study). International Journal of Cancer 132 924-931. (doi:10.1002/ijc.27669)
Michalik L, Desvergne B \& Wahli W 2004 Peroxisome-proliferatoractivated receptors and cancers: complex stories. Nature Reviews Cancer 4 61-70. (doi:10.1038/nrc1254)

Millard CJ, Watson PJ, Fairall L \& Schwabe JWR 2013 An evolving understanding of nuclear receptor coregulator proteins. Journal of Molecular Endocrinology 51 T23-T36. (doi:10.1530/JME-13-0227)

Miranda TB, Voss TC, Sung M-H, Baek S, John S, Hawkins M, Grontved L, Schiltz RL \& Hager GL 2013 Reprogramming the chromatin landscape: interplay of the estrogen and glucocorticoid receptors at the genomic level. Cancer Research 73 5130-5139. (doi:10.1158/00085472.CAN-13-0742)

Mohammed H, Russell IA, Stark R, Rueda OM, Hickey TE, Tarulli GA, Serandour AA, Birrell SN, Bruna A, Saadi A, et al. 2015 Progesterone receptor modulates ERalpha action in breast cancer. Nature $\mathbf{5 2 3}$ 313-317. (doi:10.1038/nature14583)

Moore LD, Isayeva T, Siegal GP \& Ponnazhagan S 2008 Silencing of transforming growth factor-beta1 in situ by RNA interference for breast cancer: implications for proliferation and migration in vitro and metastasis in vivo. Clinical Cancer Research 14 4961-4970. (doi:10.1158/1078-0432.CCR-07-4604)

Mootha VK, Handschin C, Arlow D, Xie X, St Pierre J, Sihag S, Yang W, Altshuler D, Puigserver P, Patterson N, et al. 2004 Erralpha and Gabpa/b specify PGC-1alpha-dependent oxidative phosphorylation gene expression that is altered in diabetic muscle. PNAS 101 6570-6575. (doi:10.1073/pnas.0401401101)

Mote PA, Bartow S, Tran N \& Clarke CL 2002 Loss of co-ordinate expression of progesterone receptors A and B is an early event in breast carcinogenesis. Breast Cancer Research and Treatment 72 163-172. (doi:10.1023/A:1014820500738)

Mote PA, Gompel A, Howe C, Hilton HN, Sestak I, Cuzick J, Dowsett M, Hugol D, Forgez P, Byth K, et al. 2015 Progesterone receptor A predominance is a discriminator of benefit from endocrine therapy in the ATAC trial. Breast Cancer Research and Treatment 151 309-318. (doi:10.1007/s10549-015-3397-0)

Muscat GEO, Eriksson NA, Byth K, Loi S, Graham D, Jindal S, Davis MJ, Clyne C, Funder JW, Simpson ER, et al. 2013 Research resource: nuclear receptors as transcriptome: discriminant and prognostic value in breast cancer. Molecular Endocrinology 27 350-365. (doi:10.1210/me.2012-1265)

Navab R, Gonzalez-Santos JM, Johnston MR, Liu J, Brodt P, Tsao MS \& Hu J 2004 Expression of chicken ovalbumin upstream promotertranscription factor II enhances invasiveness of human lung carcinoma cells. Cancer Research 64 5097-5105. (doi:10.1158/00085472.CAN-03-1185)

Ni M, Chen Y, Lim E, Wimberly H, Bailey ST, Imai Y, Rimm DL, Liu XS \& Brown M 2011 Targeting androgen receptor in estrogen receptornegative breast cancer. Cancer Cell 20 119-131. (doi:10.1016/j. ccr.2011.05.026)

O'Leary ES, Schoenfeld ER, Stevens RG, Kabat GC, Henderson K, Grimson R, Gammon MD \& Leske MC 2006 Shift work, light at night, and breast cancer on Long Island, New York. American Journal of Epidemiology 164 358-366. (doi:10.1093/aje/kwj211)

Ohshiro K, Schwartz AM, Levine PH \& Kumar R 2012 Alternate estrogen receptors promote invasion of inflammatory breast cancer cells via non-genomic signaling. PLOS ONE $\mathbf{7}$ e30725. (doi:10.1371/journal. pone.0030725)

Oishi K, Miyazaki K, Kadota K, Kikuno R, Nagase T, Atsumi G, Ohkura N, Azama T, Mesaki M, Yukimasa S, et al. 2003 Genome-wide expression analysis of mouse liver reveals CLOCK-regulated circadian output genes. Journal of Biological Chemistry 278 41519-41527. (doi:10.1074/jbc.M304564200)

Oishi K, Amagai N, Shirai H, Kadota K, Ohkura N \& Ishida N 2005 Genome-wide expression analysis reveals 100 adrenal glanddependent circadian genes in the mouse liver. DNA Research 12 191-202. (doi:10.1093/dnares/dsi003) http://jme.endocrinology-journals.org

DOI: 10.1530/JME-16-0082
() 2017 Society for Endocrinology Printed in Great Britain
Published by Bioscientifica Ltd 
Ottow E \& Weinmann H 2008 Nuclear receptors as drug targets: a historical perspective of modern drug discovery. In Nuclear Receptors as Drug Targets, pp 1-23. Weinheim, Germany: Wiley-VCH Verlag GmbH \& Co. KGaA. (doi:10.1002/9783527623297.ch1)

Pan D, Kocherginsky M \& Conzen SD 2011 Activation of the glucocorticoid receptor is associated with poor prognosis in estrogen receptor-negative breast cancer. Cancer Research 71 6360-6370. (doi:10.1158/0008-5472.CAN-11-0362)

Papantoniou K, Castano-Vinyals G, Espinosa A, Aragones N, PerezGomez B, Ardanaz E, Altzibar JM, Sanchez VM, Gomez-Acebo I, Llorca J, et al. 2015 Breast cancer risk and night shift work in a casecontrol study in a Spanish population. European Journal of Epidemiology 31 867-878. (doi:10.1007/s10654-015-0073-y)

Park S, Koo J, Park HS, Kim JH, Choi SY, Lee JH, Park BW \& Lee KS 2010 Expression of androgen receptors in primary breast cancer. Annals of Oncology 21 488-492. (doi:10.1093/annonc/mdp510)

Perou CM, Sorlie T, Eisen MB, van de Rijn M, Jeffrey SS, Rees CA, Pollack JR, Ross DT, Johnsen H, Akslen LA, et al. 2000 Molecular portraits of human breast tumours. Nature 406 747-752. (doi:10.1038/35021093)

Peters AA, Buchanan G, Ricciardelli C, Bianco-Miotto T, Centenera MM, Harris JM, Jindal S, Segara D, Jia L, Moore NL, et al. 2009 Androgen receptor inhibits estrogen receptor-alpha activity and is prognostic in breast cancer. Cancer Research 69 6131-6140. (doi:10.1158/00085472.CAN-09-0452)

Pon CK, Firth SM \& Baxter RC 2015 Involvement of insulin-like growth factor binding protein-3 in peroxisome proliferator-activated receptor gamma-mediated inhibition of breast cancer cell growth. Molecular and Cellular Endocrinology 399 354-361. (doi:10.1016/j.mce.2014.10.023)

Prat A, Pineda E, Adamo B, Galvan P, Fernandez A, Gaba L, Diez M, Viladot M, Arance A \& Munoz M 2015 Clinical implications of the intrinsic molecular subtypes of breast cancer. Breast 24 (Supplement 2) S26-S35. (doi:10.1016/j.breast.2015.07.008)

Preitner N, Damiola F, Lopez-Molina L, Zakany J, Duboule D, Albrecht U \& Schibler U 2002 The orphan nuclear receptor REV-ERBalpha controls circadian transcription within the positive limb of the mammalian circadian oscillator. Cell 110 251-260. (doi:10.1016/ S0092-8674(02)00825-5)

Pronk A, Ji BT, Shu XO, Xue S, Yang G, Li HL, Rothman N, Gao YT, Zheng W \& Chow WH 2010 Night-shift work and breast cancer risk in a cohort of Chinese women. American Journal of Epidemiology $\mathbf{1 7 1}$ 953-959. (doi:10.1093/aje/kwq029)

Rabstein S, Harth V, Pesch B, Pallapies D, Lotz A, Justenhoven C, Baisch C, Schiffermann M, Haas S, Fischer HP, et al. 2013 Night work and breast cancer estrogen receptor status-results from the German GENICA study. Scandinavian Journal of Work, Environment and Health 39 448-455. (doi:10.5271/sjweh.3360)

Ray P, Stacer AC, Fenner J, Cavnar SP, Meguiar K, Brown M, Luker KE \& Luker GD 2015 CXCL12-gamma in primary tumors drives breast cancer metastasis. Oncogene 34 2043-2051. (doi:10.1038/onc.2014.157)

Robinson JL, Macarthur S, Ross-Innes CS, Tilley WD, Neal DE, Mills IG \& Carroll JS 2011 Androgen receptor driven transcription in molecular apocrine breast cancer is mediated by FoxA1. EMBO Journal 30 3019-3027. (doi:10.1038/emboj.2011.216)

Rosin G, de Boniface J, Karthik GM, Frisell J, Bergh J \& Hartman J 2014 Oestrogen receptors beta 1 and betacx have divergent roles in breast cancer survival and lymph node metastasis. British Journal of Cancer 111 918-926. (doi:10.1038/bjc.2014.398)

Ross-Innes CS, Stark R, Holmes KA, Schmidt D, Spyrou C, Russell R, Massie CE, Vowler SL, Eldridge M \& Carroll JS 2010 Cooperative interaction between retinoic acid receptor-alpha and estrogen receptor in breast cancer. Genes and Development 24 171-182. (doi:10.1101/gad.552910)

Ross-Innes CS, Stark R, Teschendorff AE, Holmes KA, Ali HR, Dunning MJ, Brown GD, Gojis O, Ellis IO, Green AR, et al. 2012 Differential oestrogen receptor binding is associated with clinical outcome in breast cancer. Nature 481 389-393. (doi:10.1038/nature10730)
Sailland J, Tribollet V, Forcet C, Billon C, Barenton B, Carnesecchi J, Bachmann A, Gauthier KC, Yu S, Giguere V, et al. 2014 Estrogenrelated receptor a decreases RHOA stability to induce orientated cell migration. PNAS 111 15108-15113. (doi:10.1073/pnas.1402094111)

Sakharkar MK, Shashni B, Sharma K, Dhillon SK, Ranjekar PR \& Sakharkar KR 2013 Therapeutic implications of targeting energy metabolism in breast cancer. PPAR Research 2013109285. (doi:10.1155/2013/109285)

Sanchez AM, Flamini MI, Baldacci C, Goglia L, Genazzani AR \& Simoncini T 2010 Estrogen receptor-alpha promotes breast cancer cell motility and invasion via focal adhesion kinase and N-WASP. Molecular Endocrinology 24 2114-2125. (doi:10.1210/me.2010-0252)

Schernhammer ES, Laden F, Speizer FE, Willett WC, Hunter DJ, Kawachi I \& Colditz GA 2001 Rotating night shifts and risk of breast cancer in women participating in the nurses' health study. Journal of the National Cancer Institute 93 1563-1568. (doi:10.1093/jnci/93.20.1563)

Schernhammer ES, Kroenke CH, Laden F \& Hankinson SE 2006 Night work and risk of breast cancer. Epidemiology 17 108-111. (doi:10.1097/01.ede.0000190539.03500.c1)

Stein RA, Chang CY, Kazmin DA, Way J, Schroeder T, Wergin M, Dewhirst MW \& McDonnell DP 2008 Estrogen-related receptor alpha is critical for the growth of estrogen receptor-negative breast cancer. Cancer Research 68 8805-8812. (doi:10.1158/0008-5472.CAN08-1594)

Stein RA, Gaillard S \& McDonnell DP 2009 Estrogen-related receptor alpha induces the expression of vascular endothelial growth factor in breast cancer cells. Journal of Steroid Biochemistry and Molecular Biology 114 106-112. (doi:10.1016/j.jsbmb.2009.02.010)

Surjit M, Ganti KP, Mukherji A, Ye T, Hua G, Metzger D, Li M \& Chambon P 2011 Widespread negative response elements mediate direct repression by agonist-liganded glucocorticoid receptor. Cell 145 224-241. (doi:10.1016/j.cell.2011.03.027)

Tang Q, Chen Y, Meyer C, Geistlinger T, Lupien M, Wang Q, Liu T, Zhang Y, Brown M \& Liu XS 2011 A comprehensive view of nuclear receptor cancer cistromes. Cancer Research 71 6940-6947. (doi:10.1158/0008-5472.CAN-11-2091)

Thewes V, Simon R, Schroeter P, Schlotter M, Anzeneder T, Buettner R, Benes V, Sauter G, Burwinkel B, Nicholson RI, et al. 2015 Reprogramming of the ERR alpha and ER alpha target gene landscape triggers tamoxifen resistance in breast cancer. Cancer Research 75 720-731. (doi:10.1158/0008-5472.CAN-14-0652)

Tiraby C, Hazen BC, Gantner ML \& Kralli A 2011 Estrogen-related receptor gamma promotes mesenchymal-to-epithelial transition and suppresses breast tumor growth. Cancer Research $712518-2528$. (doi:10.1158/0008-5472.CAN-10-1315)

Treuting PM, Chen LI, Buetow BS, Zeng W, Birkebak TA, Seewaldt VL, Sommer KM, Emond M, Maggio-Price L \& Swisshelm K 2002 Retinoic acid receptor beta2 inhibition of metastasis in mouse mammary gland xenografts. Breast Cancer Research and Treatment 72 79-88. (doi:10.1023/A:1014906529407)

Vazquez A, Liu J, Zhou Y \& Oltvai ZN 2010 Catabolic efficiency of aerobic glycolysis: the Warburg effect revisited. BMC Systems Biology 4 58. (doi:10.1186/1752-0509-4-58)

Vilasco M, Communal L, Mourra N, Courtin A, Forgez P \& Gompel A 2011 Glucocorticoid receptor and breast cancer. Breast Cancer Research and Treatment 130 1-10. (doi:10.1007/s10549-011-1689-6)

Viswanathan AN \& Schernhammer ES 2009 Circulating melatonin and the risk of breast and endometrial cancer in women. Cancer Letters 281 1-7. (doi:10.1016/j.canlet.2008.11.002)

Wang F, Yeung KL, Chan WC, Kwok CC, Leung SL, Wu C, Chan EY, Yu IT, Yang XR \& Tse LA 2013 A meta-analysis on dose-response relationship between night shift work and the risk of breast cancer. Annals of Oncology 24 2724-2732. (doi:10.1093/annonc/mdt283)

Ward PS \& Thompson CB 2012 Metabolic reprogramming: a cancer hallmark even warburg did not anticipate. Cancer Cell 21 297-308. (doi:10.1016/j.ccr.2012.02.014) 
Xiang S, Mao L, Duplessis T, Yuan L, Dauchy R, Dauchy E, Blask DE, Frasch T \& Hill SM 2012 Oscillation of clock and clock controlled genes induced by serum shock in human breast epithelial and breast cancer cells: regulation by melatonin. Breast Cancer 6 137-150.

Xiang SL, Dauchy RT, Hauch A, Mao LL, Yuan L, Wren MA, Belancio VP, Mondal D, Frasch T, Blask DE, et al. 2015 Doxorubicin resistance in breast cancer is driven by light at night-induced disruption of the circadian melatonin signal. Journal of Pineal Research 59 60-69. (doi:10.1111/jpi.12239)

Xiao L, Chang AK, Zang MX, Bi H, Li S, Wang M, Xing X \& Wu H 2014 Induction of the CLOCK gene by E2-ERalpha signaling promotes the proliferation of breast cancer cells. PLOS ONE 9 e95878. (doi:10.1371/ journal.pone.0095878)

Xie D, Boyle Alan P, Wu L, Zhai J, Kawli T \& Snyder M 2013 Dynamic trans-acting factor colocalization in human cells. Cell 155 713-724. (doi:10.1016/j.cell.2013.09.043)

Xu XC, Sneige N, Liu X, Nandagiri R, Lee JJ, Lukmanji F, Hortobagyi G, Lippman SM, Dhingra K \& Lotan R 1997 Progressive decrease in nuclear retinoic acid receptor beta messenger RNA level during breast carcinogenesis. Cancer Research 57 4992-4996.

Yang QF, Sakurai T \& Kakudo K 2002 Retinoid, retinoic acid receptor beta and breast cancer. Breast Cancer Research and Treatment 76 167-173. (doi:10.1023/A:1020576606004)

Yao P-L, Morales JL, Zhu B, Kang B-H, Gonzalez FJ \& Peters JM 2014 Activation of peroxisome proliferator-activated receptor-beta/delta (ppar-beta/delta) inhibits human breast cancer cell line tumorigenicity. Molecular Cancer Therapeutics 13 1008-1017. (doi:10.1158/1535-7163.MCT-13-0836)

Zhang YX, Fang B, Emmett MJ, Damle M, Sun Z, Feng D, Armour SM, Remsberg JR, Jager J, Soccio RE, et al. 2015 Discrete functions of nuclear receptor Rev-erb alpha couple metabolism to the clock. Science 348 1488-1492. (doi:10.1126/science.aab3021)

Zhao YH, Zhou M, Liu H, Ding Y, Khong HT, Yu D, Fodstad O \& Tan M 2009 Upregulation of lactate dehydrogenase A by ErbB2 through heat shock factor 1 promotes breast cancer cell glycolysis and growth. Oncogene 28 3689-3701. (doi:10.1038/onc.2009.229)

Zhao Y, Li Y, Lou G, Zhao L, Xu Z, Zhang Y \& He F 2012 MiR-137 targets estrogen-related receptor alpha and impairs the proliferative and migratory capacity of breast cancer cells. PLOS ONE 7 e39102. (doi:10.1371/journal.pone.0039102)

Zhao X, Cho H, Yu RT, Atkins AR, Downes M \& Evans RM 2014 Nuclear receptors rock around the clock. EMBO Reports 15 518-528. (doi:10.1002/embr.201338271)

Zheng S, Huang J, Zhou K, Zhang C, Xiang Q, Tan Z, Wang T \& Fu X 2011 17beta-Estradiol enhances breast cancer cell motility and invasion via extra-nuclear activation of actin-binding protein ezrin. PLOS ONE 6 e22439. (doi:10.1371/journal.pone.0022439)

Zhou F, Drabsch Y, Dekker TJA, de Vinuesa AG, Li Y, Hawinkels LJAC, Sheppard K-A, Goumans M-J, Luwor RB, de Vries CJ, et al. 2014 Nuclear receptor NR4A1 promotes breast cancer invasion and metastasis by activating TGF-beta signalling. Nature Communications 5 3388. (doi:10.1038/ncomms5573)

Zhou Y, Ming J, Xu Y, Zhang Y \& Jiang J 2015 ER beta 1 inhibits the migration and invasion of breast cancer cells through upregulation of E-cadherin in a Id1-dependent manner. Biochemical and Biophysical Research Communications 457 141-147. (doi:10.1016/j.bbrc.2014.12.038)

Zwart W, Theodorou V, Kok M, Canisius S, Linn S \& Carroll JS 2011 Oestrogen receptor-co-factor-chromatin specificity in the transcriptional regulation of breast cancer. EMBO Journal $\mathbf{3 0}$ 4764-4776. (doi:10.1038/emboj.2011.368)

Received in final form 13 December 2016

Accepted 12 January 2017

Accepted Preprint published online 13 January 2017
๑ 2017 Society for Endocrinology Printed in Great Britain 